\title{
Palmitic Acid and Oleic Acid Differently Modulate TLR2-Mediated Inflammatory Responses in Microglia and Macrophages
}

\author{
Anne-Marie Howe ${ }^{1,2} \cdot$ Sinéad Burke ${ }^{1,2} \cdot$ Marcella E. O'Reilly ${ }^{2,3} \cdot$ Fiona C. McGillicuddy ${ }^{2,3} \cdot$ Derek A. Costello $^{1,2}$ (D
}

Received: 18 October 2021 / Accepted: 17 January 2022 / Published online: 25 January 2022

(c) The Author(s) 2022

\begin{abstract}
The relationship between systemic immunity and neuroinflammation is widely recognised. Infiltration of peripheral immune cells to the CNS during certain chronic inflammatory states contributes significantly to neuropathology. Obesity and its co-morbidities are primary risk factors for neuroinflammatory and neurodegenerative conditions, including Alzheimer's disease (AD). Dietary fats are among the most proinflammatory components of the obesogenic diet and play a prominent role in the low-grade systemic inflammation associated with the obese state. Saturated fatty acid (SFA) is largely implicated in the negative consequences of obesity, while the health benefits of monounsaturated fatty acid (MUFA) are widely acknowledged. The current study sought to explore whether SFA and MUFA differently modulate inflammatory responses in the brain, compared with peripheral immune cells. Moreover, we assessed the neuroinflammatory impact of high-fatinduced obesity and hypothesised that a MUFA-rich diet might mitigate inflammation despite obesogenic conditions. Tolllike receptor (TLR)2 mediates the inflammation associated with both obesity and AD. Using the TLR2 agonist lipoteichoic acid (LTA), we report that pre-exposure to either palmitic acid (PA) or oleic acid (OA) attenuated cytokine secretion from microglia, but heightened sensitivity to nitric oxide (NO) production. The reduction in cytokine secretion was mirrored in LTA-stimulated macrophages following exposure to PA only, while effects on NO were restricted to OA, highlighting important cell-specific differences. An obesogenic diet over 12 weeks did not induce prominent inflammatory changes in either cortex or hippocampus, irrespective of fat composition. However, we reveal a clear disparity in the effects of MUFA under obesogenic and non-obesogenic conditions.
\end{abstract}

Keywords Palmitic acid $\cdot$ Oleic acid $\cdot$ Diet-induced obesity $\cdot$ Nitric oxide $\cdot$ Cytokine $\cdot$ Microglia

\section{Introduction}

Neuroinflammation is the specific response that occurs within the central nervous system (CNS) in response to damage or infection. The degree of neuroinflammation is influenced by a variety of factors, including the duration and the source of the insult [1]. Acute inflammation comprises the immediate and early response against an infectious agent and is the first line of defence which aims to remove the

Derek A. Costello

derek.costello@ucd.ie

1 UCD School of Biomolecular \& Biomedical Science, University College Dublin, Dublin 4, Ireland

2 UCD Conway Institute, University College Dublin, Dublin 4, Ireland

3 UCD School of Medicine, University College Dublin, Dublin 4, Ireland insult and repair the damage. In contrast, chronic inflammation results from a more persistent inflammatory stimulus and is integral to the pathogenesis of CNS disease [2]. Neuroinflammation underlies various CNS conditions, including those of psychiatric nature such as anxiety [3,4] and depression [5, 6]. In addition, it is central to the pathology of neurodegenerative diseases such as Parkinson's disease (PD) $[7,8]$ and Alzheimer's disease (AD) [9]. This is generally understood to result from dysregulation of microglial activation, favouring a chronic production of proinflammatory mediators that promote pathological changes and neurobehavioural complications such as depression and cognitive deficits [10]. Moreover, chronically activated cells can disrupt the integrity of the blood-brain barrier (BBB), leading to infiltration of systemic immune cells and mediators, which further exacerbates the proinflammatory environment in the CNS [11]. 
The impact of inflammatory insults on neuronal and cognitive dysfunction has been widely reported, and we among others have illustrated the key role of microglial Toll-like receptors (TLRs) in mediating these effects [12-17]. In recent years, TLR2 has been implicated as a critical regulator of inflammation in the brain $[18,19]$. While primarily a sensor for bacterial-derived pathogens, its role in disease pathogenesis is largely due to its ability to recognise protein aggregates including $\beta$-amyloid $(\mathrm{A} \beta)$ and $\alpha$-synuclein [20, $21]$ along with other endogenous damage signals. Research including our own has highlighted the negative impact of TLR2 stimulation on microglial activation and the integrity of neuronal activity [13, 22-24]. In aged and AD-like experimental models, the degree of neuroinflammation and neuronal impairment is coupled to BBB disruption and infiltration of systemic immune cells $[25,26]$. In particular, the contribution of macrophages to promoting the microglial activation and neuronal dysfunction associated with these conditions has been well explored [27-29].

Obesity is widely recognised among the world's most significant population and healthcare challenges, with incidences expected to rise to $14.2 \%$ of the global population by the year 2030 [30]. It is characterised by the excessive accumulation of adipose tissue, a collection of adipocytes and associated stromal vascular fraction cells that secrete adipokines including proinflammatory cytokines, chemokines and hormones [31,32]. Obesity is also associated with increased recruitment of proinflammatory M1 macrophages into adipose tissue further contributing to the proinflammatory milieu [33]. Together this facilitates the low-grade systemic inflammation which is characteristic of the obesogenic state [34]. Along with common comorbidities [35-37], obesity is associated with brain atrophy and cognitive decline [38-41] and increases risk of developing dementia and $\mathrm{AD}$ [42]. Moreover, higher levels of $A \beta$ have been identified in obese individuals $[43,44]$, and diet-induced obesity markedly increases $\mathrm{A} \beta$ burden in animal models of $\mathrm{AD}[45,46]$.

The mechanisms through which obesity influences cognitive ability are largely unknown; however, it is likely that the systemic inflammatory environment precipitates brain dysfunction [42]. Indeed, lipopolysaccharide (LPS) challenge in rats with diet-induced obesity (DIO) resulted in an enhanced and prolonged fever in addition to an increase in circulating TNF- $\alpha$ and IL6 [47]. Similar inflammatory changes have been reported in hippocampus of leptin receptor-deficient animals, accompanied by cognitive and behavioural deficits [48]. Integrity of the BBB is impaired by obesity [49-52], offering a route for infiltration of inflammatory cells and mediators to the CNS, similar to that reported with age and AD [26, 53, 54]. Little, however, is currently understood about how nutritional composition within an obesogenic diet, independent of weight gain, may impact on neuroinflammation. Over-consumption of saturated fatty acids (SFAs) is widely associated with obesity
$[55,56]$. Within the CNS, a fat-rich diet is known to induce inflammation [57], facilitate infiltration of immune cells [51, 52] and accelerate the cognitive decline associated with $\mathrm{AD}$ [58]. Conversely, unsaturated fats are reported for their antiinflammatory properties [56] and are proven to convey cognitive and neuroprotective benefits [59-61]. Consumption of the monounsaturated fatty acid (MUFA)-enriched Mediterranean diet is associated with reduced risk of cognitive impairment and reduced dysfunction in experimental models of $\mathrm{AD}$ $[62,63]$, while postprandial lipoproteins isolated following a MUFA-rich meal bias microglia towards adoption of an antiinflammatory phenotype [64]. Similarly, obesity-induced proinflammatory changes in adipose tissue are reduced by replacement of SFA for MUFA, despite equivalent weight gain [56]. Little, however, is understood about the potential impact of replacing dietary SFA for MUFA on obesity-associated neuroinflammation.

The majority of evidence implicates TLRs as the primary interface between free fatty acids and NF-kB-dependent production of proinflammatory mediators in macrophages and adipocytes [65-67]. Indeed, the SFA lauric acid has been reported to promote both TLR4- and TLR2-mediated NF- $\mathrm{KB}$ and cyclooxygenase (COX) 2 activation in macrophages, whereas this is mitigated in the presence of PUFA [68, 69]. As free fatty acids can access the brain, it is likely that they may act similarly in the resident cells to initiate an inflammatory response. Palmitic acid (PA), the most common SFA, has been shown to modulate the microglial response to LPS [70, 71]. In light of the prominent role of TLR2 in mediating neuroinflammation, the current study set out to determine the impact of PA priming on the responsiveness of BV2 microglia to the TLR2 agonist lipoteichoic acid (LTA). As the anti-inflammatory effects of MUFA have also been reported, we evaluated whether the microglial response to LTA may be differently modulated by priming with oleic acid (OA). We further assessed whether these inflammatory effects are reflected in changes in hippocampal and cortical tissue from obese mice, following an obesogenic diet rich in either SFA or MUFA. Recognising the potential impact of systemic immune mediators in the central inflammation associated with obesity, we compared our findings in microglia to those from PA- and OA-primed macrophages. Furthermore, to model the effects of macrophage infiltration to the CNS under obesogenic conditions, we assessed their activation following exposure to soluble brain extract from chronically SFA- and MUFA-fed mice.

\section{Materials and Methods}

\section{Diet-Induced Obesity (DIO) Model}

Male C57BL/6 mice (Harlan, UK) were randomly assigned to three feeding groups: a diet rich with SFA, in particular 
PA (45\% total $\mathrm{kCal}$ from palm oil) and a diet rich in MUFA, in particular OA (45\% total $\mathrm{kCal}$ from oleic sunflower oil) or a normal, micronutrient-matched, low-fat 'chow' diet $(10 \%$ total $\mathrm{kCal}$ from palm oil/oleic acid combination; Research Diets, USA). Animals were group-housed and weight-matched at baseline prior to starting the diets aged 6-8 weeks, and fed ad libitum for a total of 12 weeks. Food intake, body weights and fat-pad weights were monitored to confirm obesogenic phenotype as previously reported [56]. Animals were euthanised by cervical dislocation under isoflurane anaesthetic. Following decapitation, brains were rapidly removed and placed on ice-cold phosphate buffered saline (PBS; Thermo Scientific, UK). Hippocampal and temporal/parietal cortical tissues were isolated and blunt dissected. Tissue samples were flash frozen in liquid nitrogen and stored at $-80{ }^{\circ} \mathrm{C}$ for later use. All animal-based experiments were carried out at the UCD Biomedical Facility, following approval of the UCD Animal Ethics Committee and under licence from the Health Products Regulatory Authority of Ireland.

\section{Preparation of Brain Tissue Lysate and Soluble Brain Extract}

Portions of isolated cortical and hippocampal tissue (described above) were homogenised in radioimmunoprecipitation assay buffer (RIPA; containing: Tris $50 \mathrm{mM}$, $\mathrm{NaCl} 150 \mathrm{mM}, 0.5 \%$ sodium deoxycholate, sodium dodecyl sulphate (SDS) $0.1 \%$, Igepal $1 \%$, pH 8.0) supplemented with protease and phosphatase inhibitor cocktails (SigmaAldrich, UK), using a handheld homogenisation system. Homogenised samples were centrifuged at 15,000 rpm for $10 \mathrm{~min} / 4{ }^{\circ} \mathrm{C}$. Supernatants were collected and protein quantification was conducted using the bicinchoninic acid (BCA) assay (Pierce, UK). Samples were equalised with RIPA buffer and stored at $-80^{\circ} \mathrm{C}$. Separate fractions of tissue were weighed and homogenised under aseptic conditions, in sterile Tris-buffered saline (TBS; $100 \mu \mathrm{L} / 0.01 \mathrm{~g}$ ) supplemented with protease and phosphatase inhibitors [28]. The tissue suspension was centrifuged at $21,000 \mathrm{rpm}$ for $1 \mathrm{~h}$ at $4{ }^{\circ} \mathrm{C}$. The supernatant was isolated as soluble brain extract (SBE). Protein concentration was quantified using BCA assay, equalised to $1 \mathrm{mg} / \mathrm{mL}$ in sterile TBS and stored at $-80{ }^{\circ} \mathrm{C}$.

\section{BV2 and N2a Cell Culture and Treatment}

Murine BV2 microglia and N2a neuroblastoma cells were grown in Dulbecco's modified Eagle's medium (DMEM/ F12; Lonza or Sigma-Aldrich, UK) containing heatinactivated foetal bovine serum (FBS; 10\%) and penicillin-streptomycin (100 U/ml; Gibco, UK), and maintained as previously described $[17,22]$. In brief, cells were plated in 24 -well culture plates at a density of $1.5 \times 10^{5}$ cells/ well and incubated overnight in a humidified environment at $37{ }^{\circ} \mathrm{C} / 5 \% \mathrm{CO}_{2}$. BV2 cells were primed with PA or OA $(100 \mu \mathrm{M}$; Sigma-Aldrich) for $20 \mathrm{~h}$ in a final volume of 200 $\mu \mathrm{L}$ per well. PA was conjugated with fatty acid-free bovine serum albumin (BSA) and reconstituted in dimethyl sulfoxide (DMSO; Sigma-Aldrich, UK) at final concentrations of $0.004 \%$ and $0.1 \%$, respectively. OA was pre-conjugated with BSA combined with DMSO, in respective final concentrations of $0.002 \%$ and $0.07 \%$. Vehicle controls were carried out in DMEM containing 0.004\% BSA and 0.1\% DMSO. Cells were exposed to LTA $(1$ or $5 \mu \mathrm{g} / \mathrm{mL}) \pm$ PA or OA for a further $4 \mathrm{~h}$ or $24 \mathrm{~h}$, respectively. N2a cells were primed with PA, OA or vehicle as above for $6 \mathrm{~h}$, followed by $18 \mathrm{~h}$ exposure to LTA $(5 \mu \mathrm{g} / \mathrm{mL})$. To promote differentiation of a neuronal-like phenotype, $\mathrm{N} 2 \mathrm{a}$ cells were incubated and treated with DMEM containing 2\% FBS. Supernatants were harvested for later analysis of cytokine and nitrite concentration. Cells were stored at $-20{ }^{\circ} \mathrm{C}$ in RIPA buffer containing protease and phosphatase inhibitor cocktails (SigmaAldrich, UK) as previously described [22], for subsequent analysis of protein expression.

\section{Preparation of Bone Marrow-Derived Macrophages}

Bone marrow was isolated from the femurs and tibiae of 13-week-old naïve male C57BL/6 mice in DMEM as previously described [28]. In brief, the cell suspension was filtered through a $40 \mu \mathrm{m}$ nylon filter and centrifuged $(2,000 \mathrm{rpm}$, $3 \mathrm{~min})$. The supernatant was removed and the pellet was resuspended in red blood cell lysis buffer $(3 \mathrm{ml} / 1 \mathrm{~min}$; containing (mM): $\mathrm{NH}_{4} \mathrm{Cl} 155 ; \mathrm{KHCO}_{3}$ 12; EDTA 0.1) and centrifuged as above. Cells were resuspended in DMEM supplemented with filter-sterilised conditioned media from L929 cells (20\%) and incubated in $75 \mathrm{~cm}^{2}$ culture flasks for approximately 7 days. Cells were seeded in 24-well tissue culture plates at $1.5 \times 10^{5}$ cells/well and incubated overnight at $37{ }^{\circ} \mathrm{C} / 5 \% \mathrm{CO}_{2}$. BMDMs were primed with PA, OA $(100 \mu \mathrm{M})$ or vehicle for $24 \mathrm{~h}$ prior to LTA exposure $(5 \mu \mathrm{g} /$ $\mathrm{mL}$ ) for $24 \mathrm{~h}$. In a separate set of experiments, BMDMs were exposed to media containing SBE from DIO animals at a final protein concentration of $0.25 \mathrm{mg} / \mathrm{ml}(24 \mathrm{~h})$. Supernatants and cell protein lysates were harvested as above and stored at $-20{ }^{\circ} \mathrm{C}$.

\section{Determination of Supernatant Cytokine and Nitrite Concentration}

Supernatant concentration of TNF- $\alpha$ and interleukin (IL)- 6 was determined by enzyme-linked immunosorbent assay (ELISA), according to the manufacturer's guidelines (Biolegend, UK). Concentration of nitrite was measured in cell 
supernatants using the Griess assay (Sigma-Aldrich, UK) as previously described [17, 22].

\section{Western Immunoblot Analysis}

Protein lysates from BV2 cells, N2a cells, BMDMs and brain tissue were harvested in RIPA buffer, supplemented with protease and phosphatase inhibitor cocktails (SigmaAldrich, UK). Proteins (5, 10 or $20 \mu \mathrm{g}$ ) were separated using SDS-PAGE, transferred to nitrocellulose membranes and blocked in 5\% semi-skimmed milk prior to overnight incubation with antibodies against iNOS $(1: 1,000$; BD Biosciences, UK), nNOS (1:500 or 1: 1000; Cell Signaling, UK), COX2 (1:1000), PSD-99 (1:1000; Santa Cruz, USA), drebrin (1:1000; Santa Cruz, USA), synaptophysin (1:1000; Santa Cruz, USA) and $\beta$-actin (1:2,000; Santa Cruz, USA). Membranes were washed and incubated with DyLightTM $680 / 800$ fluorescent anti-mouse or anti-rabbit secondary antibodies (Thermo Scientific, UK). Fluorescent immunoreactive bands were visualised using the LI-COR Odyssey and quantified with Image Studio Lite software.

\section{Statistical Analysis}

Statistical comparisons were made using one-way analysis of variance (ANOVA), followed by post hoc NewmanKeuls analysis to examine the effects of a single variable between multiple groups. To assess the effects of two independent variables (e.g. LTA and fatty acid) and interactions between these effects, comparisons were made using twoway ANOVA followed by Bonferroni post-tests. All graphs and statistical analysis were carried out using GraphPad Prism 5 software. Statistical significance is represented as $* p<0.05,{ }^{* *} p<0.01$ and ${ }^{* * *} p<0.001$ w.r.t. vehicle control and ${ }^{\#} p<0.05,{ }^{\# \#} p<0.01$ and ${ }^{\# \# \#} p<0.001$ w.r.t. LTA-stimulated, unless otherwise stated in the figure legend.

\section{Results}

\section{Pre-exposure of BV2 Microglial Cells to PA Attenuates LTA-induced TNF- $a$, but not IL- 6 Secretion}

Having previously evaluated the impact of the TLR2 agonist LTA on BV2 cell activation [22], we used this as a model to examine the effect of PA on microglial cytokine production. Pre-exposure of BV2 cells to PA $(100 \mu \mathrm{M})$ significantly attenuated supernatant concentration of TNF- $\alpha$ in response to both low $(1 \mu \mathrm{g} / \mathrm{ml}$; Fig. 1a) and high $(5 \mu \mathrm{g} /$ $\mathrm{ml}$; Fig. 1b) LTA concentrations. That withstanding, preexposure of BV2 cells to PA did not attenuate IL-6 secretion in response to LTA at either concentration (Fig. 1c, d).
Cytokine expression was accompanied by a small increase in cellular expression of $\mathrm{COX} 2$, which reached significance following application of $5 \mu \mathrm{g} / \mathrm{mL}$ LTA, when compared to controls (Fig. 1e, f). While PA alone also appeared to marginally promote $\mathrm{COX} 2$ expression, this did not influence the LTA-induced change (Fig. 1e, f).

\section{Incubation with PA Enhances LTA-Induced NO Production from BV2 Microglia}

The production of nitric oxide (NO) has become a critical determinant of microglial activation, at least under experimental conditions [72]. To evaluate its contribution to fatty acid-related changes, expression of inducible nitric oxide synthase (iNOS) and the stable NO metabolite nitrite were evaluated in BV2 cells following priming with PA. Exposure to PA significantly enhanced LTA-induced iNOS expression following $4 \mathrm{~h} \mathrm{LTA}$ stimulation (Fig. 2a) with a similar trend observed in response to $24 \mathrm{~h}$ stimulation (Fig. 2b). Similarly, concentration of nitrite was significantly higher in the supernatant from PA-primed cells stimulated with LTA for both $4 \mathrm{~h}$ (Fig. 2c) and $24 \mathrm{~h}$ (Fig. 2d), compared with cells exposed to LTA alone (Fig. 2c, d).

\section{OA Has Opposing Effects to PA on LTA-Induced Inflammatory Changes in BV2 Microglial Cells}

Unlike that observed in the presence of PA, pre-exposure of BV2 cells to OA $(100 \mu \mathrm{M})$ did not alter TNF- $\alpha$ secretion after stimulation with LTA $(5 \mu \mathrm{g} / \mathrm{ml})$ for $4 \mathrm{~h}$ (Fig. 3a). By contrast, pre-exposure to OA significantly reduced IL-6 secretion in LTA-stimulated cells (Fig. 3b). Pre-incubation of BV2 cells with OA enhanced LTA-induced iNOS expression, which reached significance following $24 \mathrm{~h}$ LTA exposure when compared to cells treated with LTA alone (Fig. 3d). Most interestingly however, basal expression of iNOS was significantly reduced in unstimulated cells $(24 \mathrm{~h}$ only) following incubation with OA, when compared with vehicle-treated controls (Fig. 3d) This was further associated with a significant reduction in basal concentration of nitrite in OA-primed cells, compared with supernatants from cells exposed to the vehicle alone (Fig. 3e, f).

\section{PA and OA Differently Modulate Neuronal Cell Inflammation Relative to Microglial Cells}

Although not primarily responsible for immune regulation in the nervous system, neurons are known to be cytokineand NO-producing cells. Similarly to our previous finding in microglia, exposing N2a cells to PA significantly reduced LTA-induced TNF- $\alpha$ concentration (Fig. 4a), with no impact on IL-6 (Fig. 4b), when compared to un-primed cells. Meanwhile, incubation of N2a cells with OA did not impact the 
Fig. 1 Palmitic acid attenuates LTA-induced TNF- $\alpha$ release from microglia. BV2 cells were exposed to palmitic acid (PA; $100 \mu \mathrm{M})$ or vehicle control (Veh) for $24 \mathrm{~h}$, and stimulated with LTA ( 1 or $5 \mu \mathrm{g} / \mathrm{mL}$ ) during the final $4 \mathrm{~h}$. Supernatant concentrations of TNF- $\alpha(\mathbf{a}, \mathbf{b})$ and IL-6 (c, d) were assessed using ELISA ( $n=9-24$ replicates). Western immunoblot was used to determine the expression of COX2 in cell lysates $(\mathbf{e}, \mathbf{f})$, relative to the expression of $\beta$-actin $(n=9-14$ replicates from 3-6 independent experiments). Data is presented as mean \pm SEM. $* * p<0.01$, *** $p<0.0001$, compared to Veh; ${ }^{++} p<0.01$, ${ }^{+++} p<0.0001$, compared with PA; ${ }^{\#} p<0.05,{ }^{\#} p<0.01$, compared with Veh + LTA; two-way ANOVA followed by Bonferroni and Newman-Keuls analysis. Inserts illustrate representative immunoreactive bands for $\mathrm{COX} 2$ and $\beta$-actin (triplicate samples)

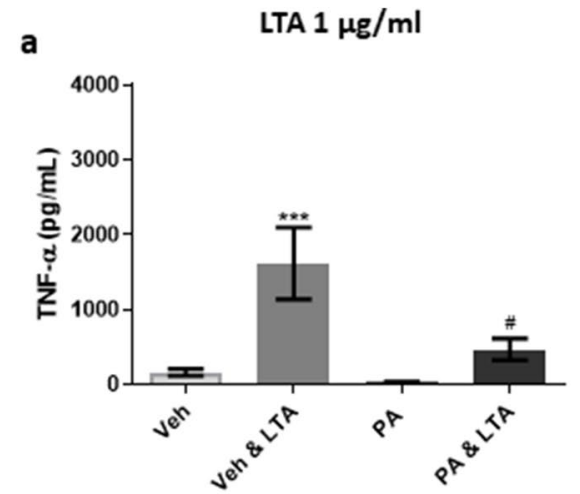

b

LTA $5 \mu g / m l$

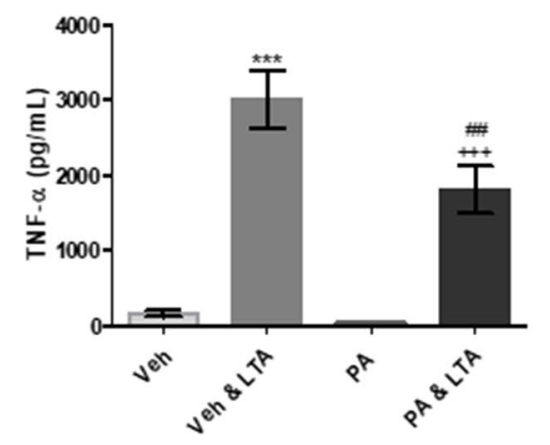

C

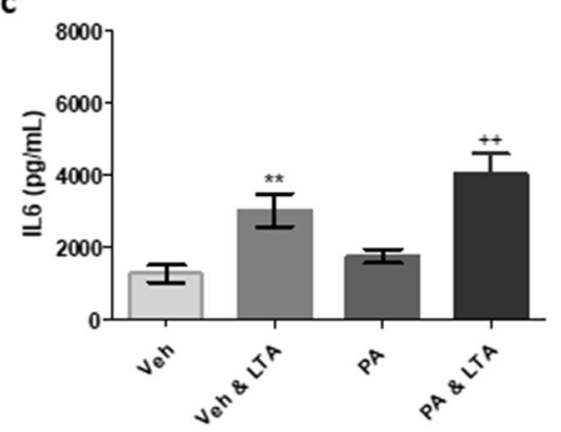

e

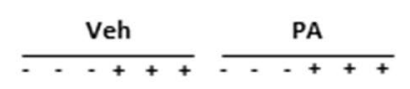

f
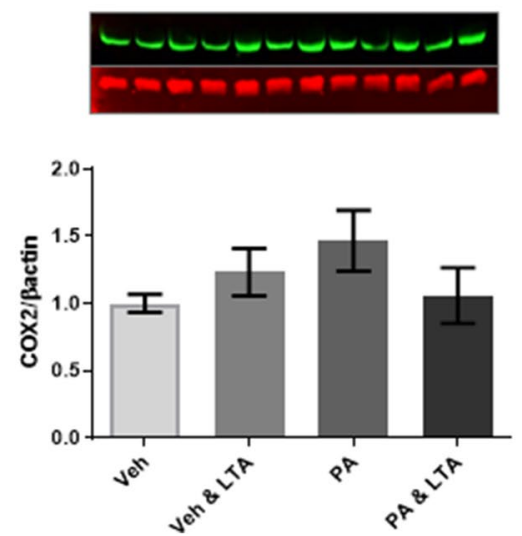

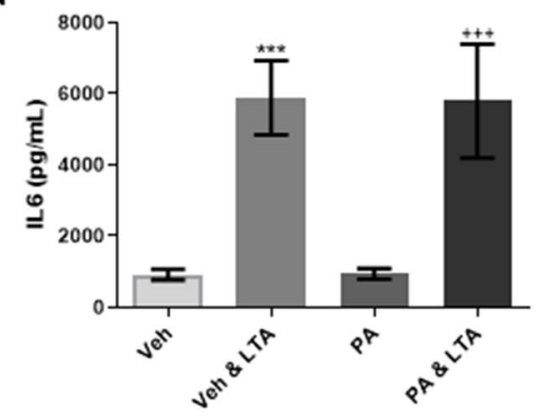

d
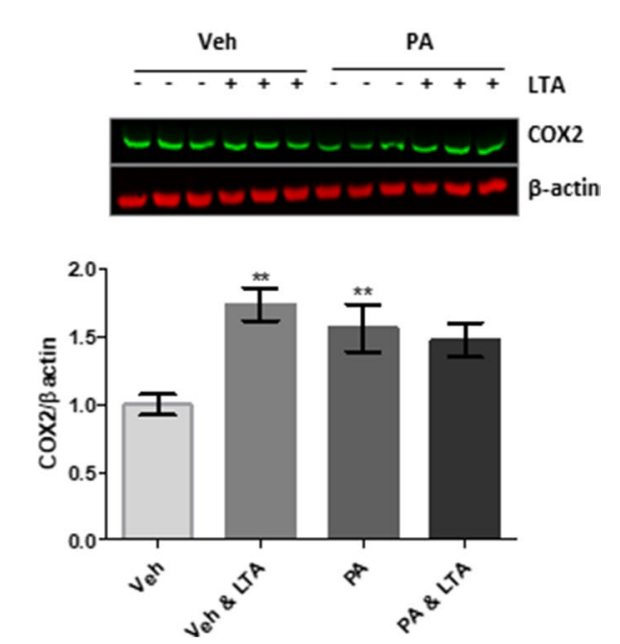

expression of either TNF- $\alpha$ or IL- 6 in the presence of LTA, compared with un-primed cells (Fig. 4a, b). Interestingly, however, neither the expression of iNOS (Fig. 4c) or nitrite (Fig. 4d) was impacted by exposure to PA or OA, either in control or LTA-stimulated cells.

\section{Differential Effects of $O A$ and $P A$ on the Inflammatory Profile of BMDMs Stimulated with LTA}

To compare the microglial response to that of their closest systemic equivalent, BMDMs prepared from naïve $\mathrm{C} 57 \mathrm{BL} / 6$ mice were primed with PA, OA $(100 \mu \mathrm{M})$ or vehicle for $24 \mathrm{~h}$, followed by the subsequent application of LTA $(5 \mu \mathrm{g}$ /
$\mathrm{mL}$ ) for a further $24 \mathrm{~h}$. Similarly to that observed in microglia and neurons, exposure to PA significantly reduced the LTA-induced release of TNF- $\alpha$ compared with un-primed cells (Fig. 5a). Unlike microglia and neurons, however, this effect also extended to LTA-stimulated IL-6 which was significantly attenuated in PA-primed cells compared to unprimed controls (Fig. 5b). Interestingly, prior exposure to OA had no impact on the concentration of either cytokine released in response to LTA (Fig. 5a, b). Also in contrast to microglia, exposure to PA did not influence the production of NO in LTA-stimulated BMDMs (Fig. 5c, d). However, the LTA-induced expression of both iNOS and nitrite was significantly increased in OA-primed cells compared with cells exposed to LTA alone (Fig. 5c, d). 
Fig. 2 Palmitic acid promotes nitric oxide production from LTA-stimulated microglia. BV2 cells were exposed to palmitic acid $(\mathrm{PA} ; 100 \mu \mathrm{M})$ or vehicle control (Veh) for $24 \mathrm{~h}$, and stimulated with LTA $(5 \mu \mathrm{g} / \mathrm{mL})$ during the final $4 \mathrm{~h}$, or for a further $24 \mathrm{~h}$. Expression of iNOS $(\mathbf{a}, \mathbf{b})$ and supernatant concentration of nitrite $(\mathbf{c}, \mathbf{d})$ were examined. Data is presented as mean $\pm \operatorname{SEM}(n=6-45$ replicates, from 3-12 independent experiments). $* * p<0.01$, $* * * p<0.0001$, compared to vehicle control; ${ }^{+++} p<0.0001$,

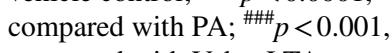
compared with Veh + LTA. Interactions based on two-way ANOVA, followed by Bonferroni post-tests. Inserts illustrate representative immunoreactive bands for iNOS and $\beta$-actin (a, b; triplicate samples)
$4 \mathrm{~h}$

a
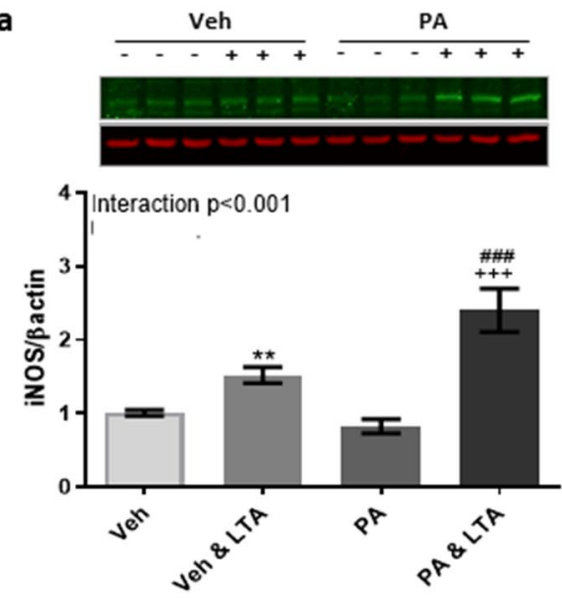

c

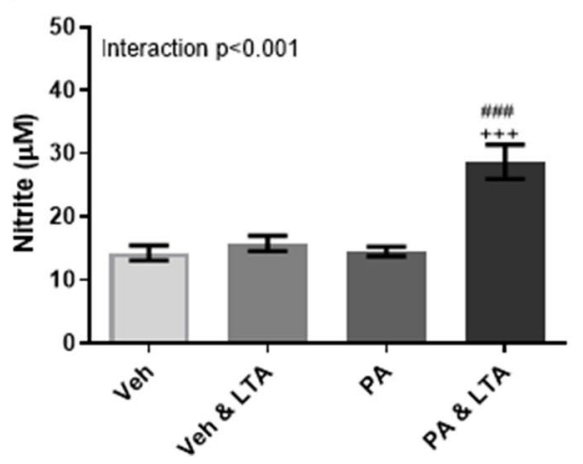

$24 \mathrm{~h}$

b
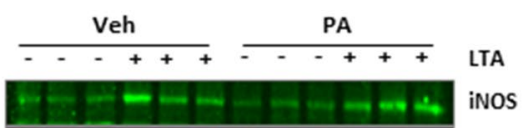

-ーーーーーーーー-ー- $\beta$-actin

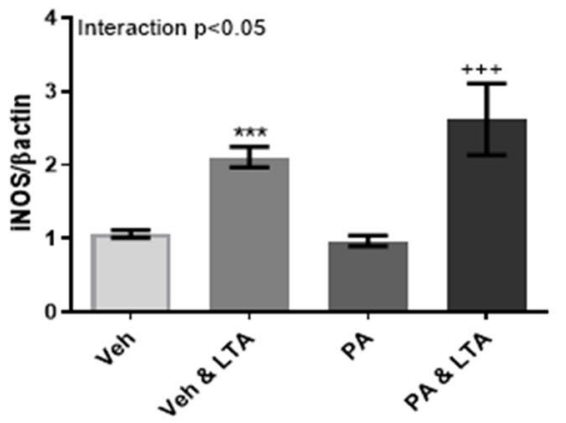

d

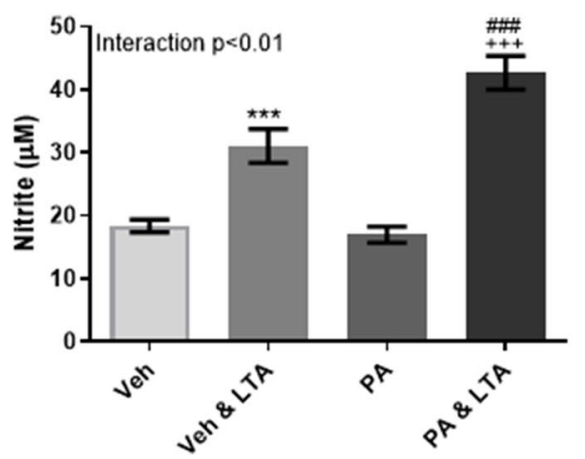

\section{Chronic Exposure to Obesogenic SFA- or MUFA-enriched High-Fat Diets Did not Impact on Synaptic Density in the Cortex or Hippocampus}

We further sought to examine how chronic exposure to SFAor MUFA-enriched HFDs in vivo affects expression of markers of synaptic integrity within the cortical and hippocampal regions of the brain. Both HFDs induced significant weight gain, insulin resistance and hypercholesterolemia as previously described [56]. No significant changes in expression of PSD-95 (Fig. 6a, b), drebrin (Fig. 6c, d, g, h) and synaptophysin (Fig. 6e, f, g, h) were observed following SFA- or MUFA-rich diets relative to tissue from non-obese controls in either brain region.

\section{Chronic Exposure to MUFA- and SFA-Enriched HFDs Differently Modulates Nitrite Concentration in the Brain}

Recognising the dual inflammatory and regulatory role of NO in the brain, we also assessed expression of iNOS (Fig. 7a, b) and nNOS (Fig. 7c, d). Interestingly, despite our previous observations in microglia, neither HFD induced significant alterations in either iNOS or nNOS when compared to tissue from low fat-fed controls. A portion of cortical tissue was used to prepare soluble brain extract (SBE), which was assessed for expression of nitrite (Fig. 7e). Although also not robustly different from chowfed controls, nitrite concentration was significantly lower in SBE from SFA-fed animals compared with those on a MUFA-rich diet (Fig. 7e (i)). Indeed, further analysis revealed an inverse relationship in nitrite concentration SBE from MUFA- and SFA-fed mice (expressed relative to expression in SBE from chow-fed animals; Fig. 7e (ii)). We have previously demonstrated the influence of brainderived inflammatory proteins on macrophage activation [28]. To model the impact on macrophages which infiltrate the brain parenchyma under obesogenic conditions, we co-incubated SBE of equal total protein concentration with cultured BMDMs prepared from naïve control mice. Independently of diet composition, SBE from all groups suppressed basal secretion of TNF- $\alpha$ from BMDMs when compared to naïve cells (Fig. 7f). However, nitrite expression was significantly higher in BMDMs exposed to SBE from chow- and SFA-fed animals compared with cells incubated with SBE from the MUFA-fed group (Fig. 7g). 
Fig. 3 Oleic acid mitigates LTA-induced release of IL-6 and basal nitrite expression in microglia. BV2 cells were exposed to oleic acid (OA; $100 \mu \mathrm{M})$ or vehicle control (Veh) for $24 \mathrm{~h}$, and stimulated with LTA $(5 \mu \mathrm{g} / \mathrm{mL})$ during the final $4 \mathrm{~h}$, or for a further $24 \mathrm{~h}$. Concentration of TNF- $\alpha(\mathbf{a})$ and IL-6 (b) was measured in the supernatant following $4 \mathrm{~h} \mathrm{LTA}$ exposure $(n=6-45$ replicates, from 3-12 independent experiments). Expression of iNOS and supernatant concentration of nitrite were examined both $4 \mathrm{~h}$ (c, e) and $24 \mathrm{~h}(\mathbf{d}, \mathbf{f})$ following LTA stimulation $(n=9-45$ replicates, from 3-12 independent experiments). Data is presented as mean \pm SEM. $* p<0.05$, $* * p<0.01, * * * p<0.0001$, compared to Veh; p $<0.001$, compared with $\mathrm{OA}$;

\#\#\# $p<0.001$, compared with Veh + LTA. Interactions based on two-way ANOVA, followed by Bonferroni post-tests. Inserts illustrate representative immunoreactive bands for iNOS and $\beta$-actin (c, d; triplicate samples) a

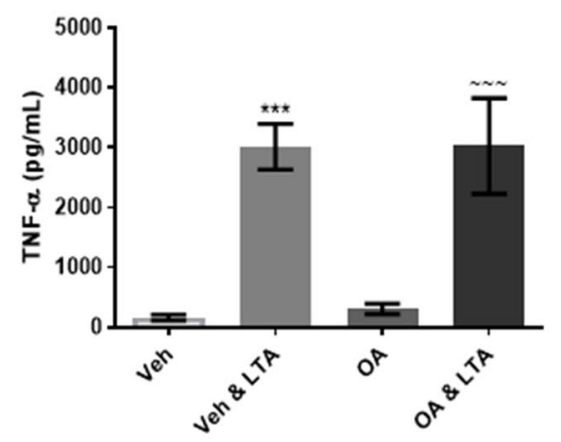

$4 \mathrm{~h}$

c
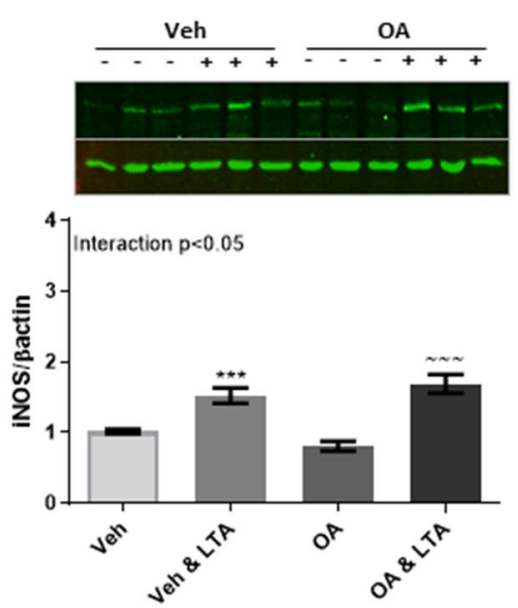

e

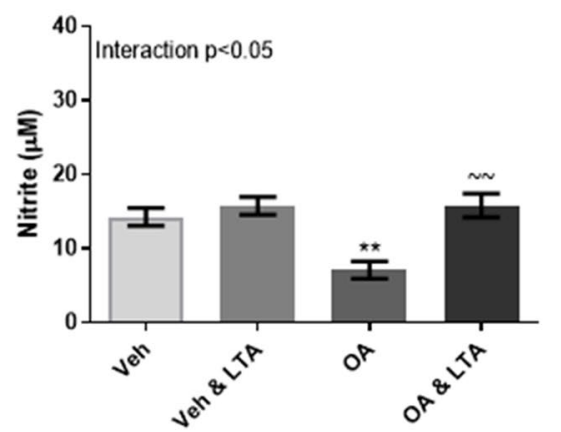

b

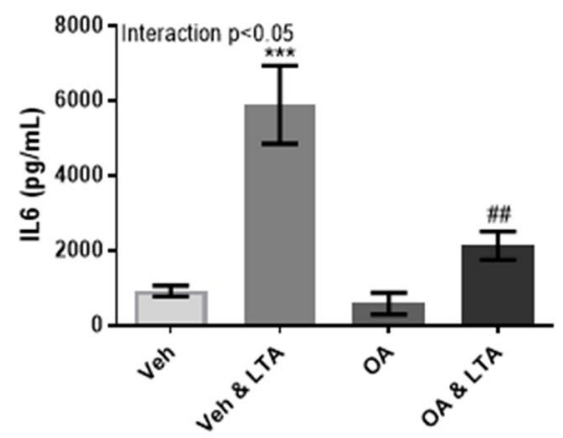

$24 \mathrm{~h}$

d
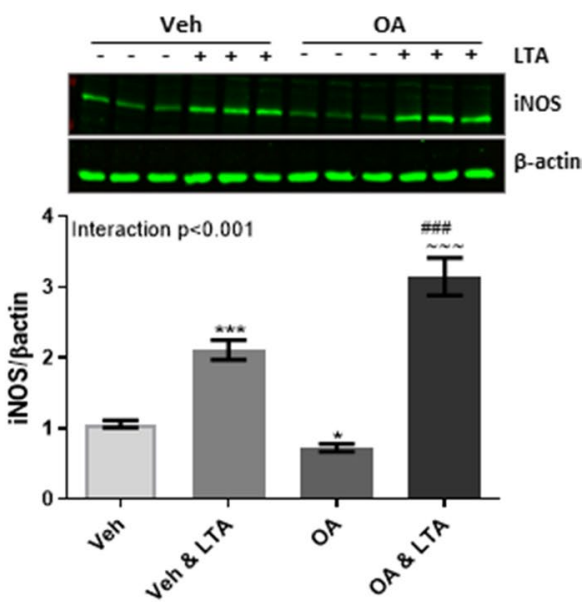

f

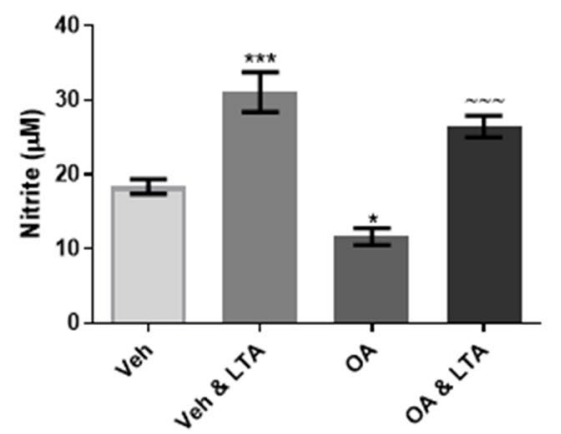

\section{Discussion}

Obesity is known to promote the risk of brain dysfunction and cognitive decline associated with neurodegenerative states [40, 42]. However, the exact mechanisms connecting these disorders remain elusive. As neuroinflammation is integral to these collective pathologies, the current study sought to explore the impact the obesogenic diet on priming the inflammatory environment in the brain and further characterise the neuroinflammatory potential of individual fatty acids in vitro/ex vivo. Dietary fats, in particular SFA such as PA, are the most proinflammatory element of an obesogenic diet, and heightened levels of PA and OA have been identified in the AD brain [73]. Therefore, we have restricted our investigation to the role of dietary fat in regulating brain inflammation. The specific role for TLR2 in obesity, and separately in $\mathrm{AD}$, has been well reported [74, 75], and we have previously described the influence of TLR2 agonists on inflammatory-induced neuronal dysfunction [22, 23]. Here we demonstrate a clear disparity between PA and OA on regulation of cytokine production, widely considered indicators of microglial activation. In particular, we report that acute exposure to PA exerts an inhibitory influence on LTA-induced TNF- $\alpha$ release. Our findings are in line with a previous report that basal secretion of TNF- $\alpha$ was mitigated in PA-exposed BV2 cells [71]; however, more specifically, we highlight that PA attenuates TNF- $\alpha$ secretion in response to LTA in both microglia and macrophages. By contrast 
Fig. 4 Neither priming with $\mathrm{PA}$ or OA alters the response to LTA in N2a neuroblastoma cells. N2a cells were incubated with PA, OA $(100 \mu \mathrm{M})$ or vehicle control (Veh) for $6 \mathrm{~h}$, prior to the inclusion of LTA $(5 \mu \mathrm{g} /$ $\mathrm{mL}$ ) for a further 18-h period. Supernatant was assessed for concentration of TNF- $\alpha(\mathbf{a})$, IL-6 (b) and nitrite (d), and cell lysates were analysed for expression of iNOS (c) ( $n=6-12$ replicates from 3-6 independent experiments). Data are presented as mean \pm SEM. ${ }^{*} p<0.05, * * p<0.01$,

$* * * p<0.001 ;{ }^{+} p<0.05$, compared to PA alone; $\sim p<0.01$ ,$\sim \sim \sim p<0.001$, compared to $\mathrm{OA}$ alone. Comparisons were made using two-way ANOVA followed by Bonferroni analysis. Inserts illustrate representative immunoreactive bands for iNOS and $\beta$-actin (c; triplicate samples)

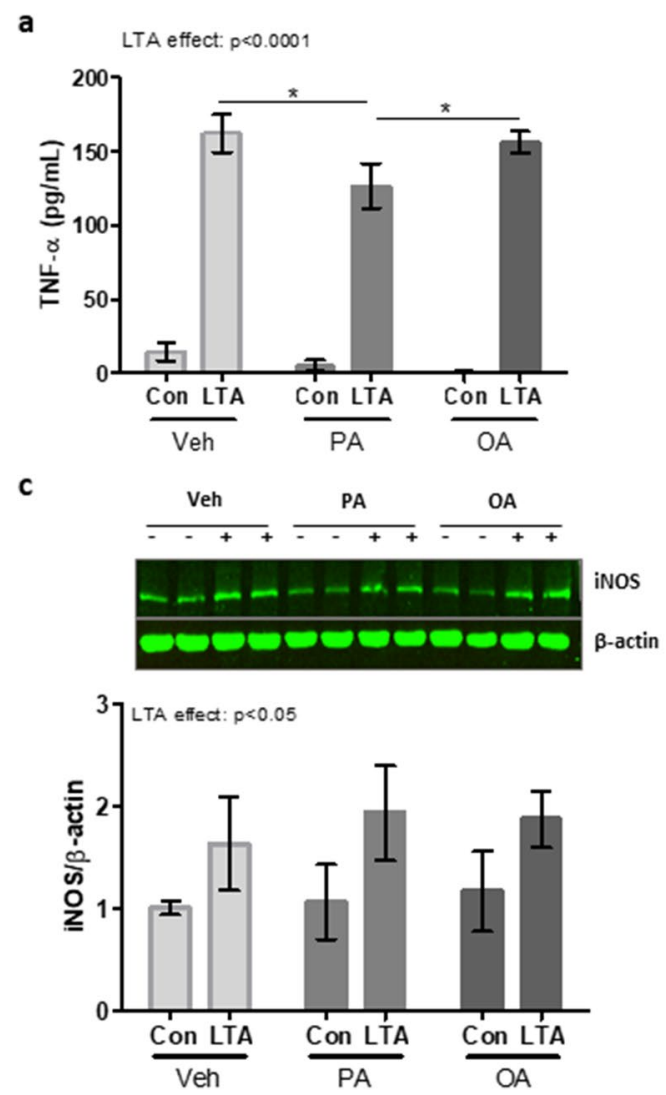

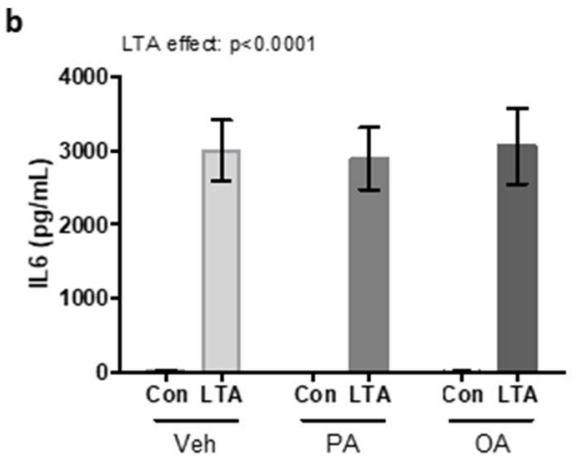

d

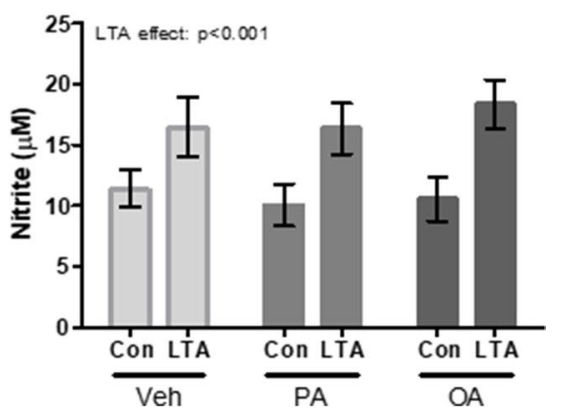

pre-incubation with PA is known to heighten LPS-induced cytokine production in microglia [67] as well as in BMDMs [76]. When considered along with previous reports [70], our findings support the observation that saturated fat does not bias microglia towards the adopting the classical state of activation seen in systemic immune cells. Consistent with our findings in microglia, priming with PA also attenuated cytokine secretion from LTA-stimulated BMDMs. Based on these findings, we speculate that PA priming likely attenuates TLR2-induced proinflammatory signalling, while the same conditions exacerbate TLR4-induced signalling as reported previously $[67,70,76]$. We hypothesise that preexposure to PA-enriched diets may augment the systemic inflammatory response to TLR4 ligands, but potentially compromise host response to TLR2 ligands. However, a future study to evaluate this effect within a TLR2-deficient model would be essential to fully assess this hypothesis. Since SFA is known to promote NF- $\mathrm{B}$ activity in macrophages [66, 69], along with post-translational cytokine processing [77], this may also suggest that PA and LTA converge on a common mechanism to disrupt cytokine production and secretion.

MUFA-rich diets are widely acknowledged for their benefits to cognitive function under challenging conditions [78], an effect which is largely ascribed to their anti-inflammatory capacity $[63,79]$. Recent evidence also supports the regulation of microglial activation as underlying the protective effects of MUFA under obesogenic conditions [64]. Consistent with this, the current study reports that while OA did not modulate TNF- $\alpha$ release, we saw a downregulation of LTA-induced IL6 concentration in OA-primed BV2 cells. Strikingly, however, we demonstrate that PA and OA differently regulate sensitivity of microglia to NO production. NO is a critical regulator of neuronal function, and production from glial cells is widely associated with neurodegenerative and neuroinflammatory states [80, 81]. Along with TNF- $\alpha$, the expression of iNOS has become a routine determinant of proinflammatory microglia [72]. Here we offer the confounding evidence that exposure to PA mitigates TNF- $\alpha$ secretion while enhancing NO production from LTA-stimulated microglia. Meanwhile, OA suppressed basal expression of NO in naïve BV2 cells, but had minimal impact upon LTA-induced NO production. These findings further highlight the complexity of fatty acids as inflammatory regulators in the brain, relative to the systemic immune system. Interestingly, supernatant expression of IL-1 $\beta$ was not detected in our samples (data not shown). Unlike previous observations in response to LPS, this data does not support a primary role for the inflammasome in mediating the FA-mediated modulation of LTA-induced inflammation.

Obesity associated with a fat-rich diet is known to promote region-specific microglial activation in the brain, 
Fig. 5 Palmitic and oleic acid differently modulates inflammatory responses in macrophages. BMDMs from C57BL/6 mice were primed with $\mathrm{PA}, \mathrm{OA}$ $(100 \mu \mathrm{M})$ or vehicle (Veh) for $24 \mathrm{~h}$, followed by the subsequent application of LTA $(5 \mu \mathrm{g} / \mathrm{mL})$ for a further $24 \mathrm{~h}$. Supernatant concentrations of TNF- $\alpha$ (a), IL-6 (b) and nitrite (d), along with cellular expression of iNOS (c), were measured. Data is presented as mean \pm SEM $(n=6-8$ replicates, from 3 independent experiments). Interaction and LTA effect determined by two-way ANOVA. $* p<0.05, * * p<0.01$, $* * * p<0.001$; Bonferroni posttests. Inserts illustrate representative immunoreactive bands for iNOS and $\beta$-actin (c; duplicate samples)
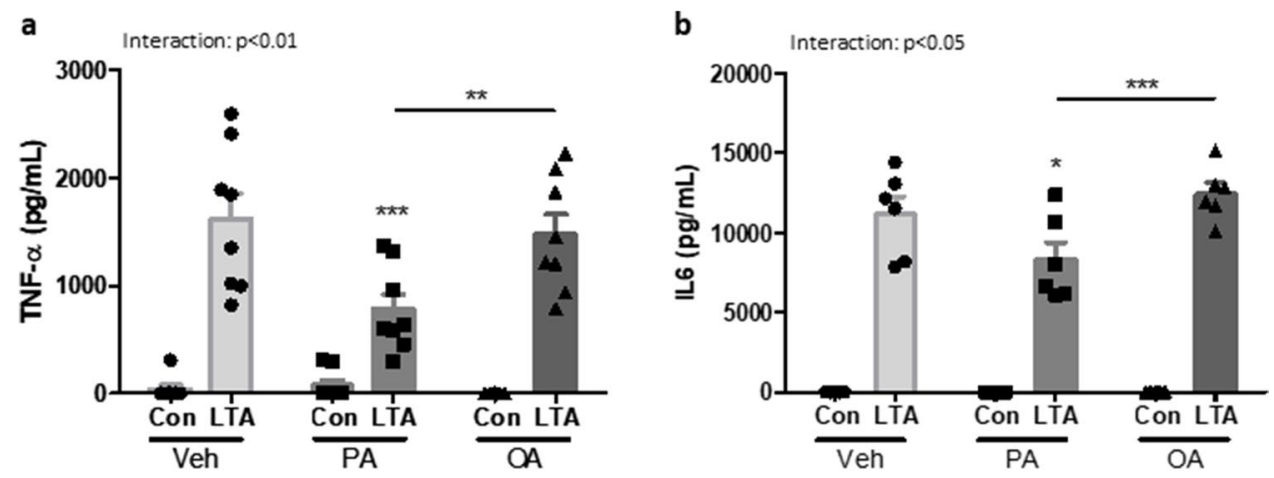

c

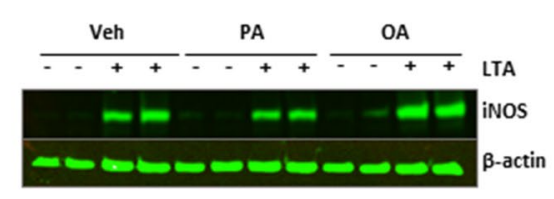

d

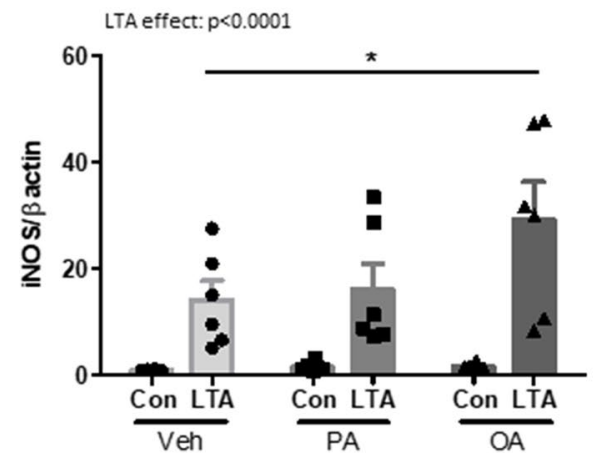

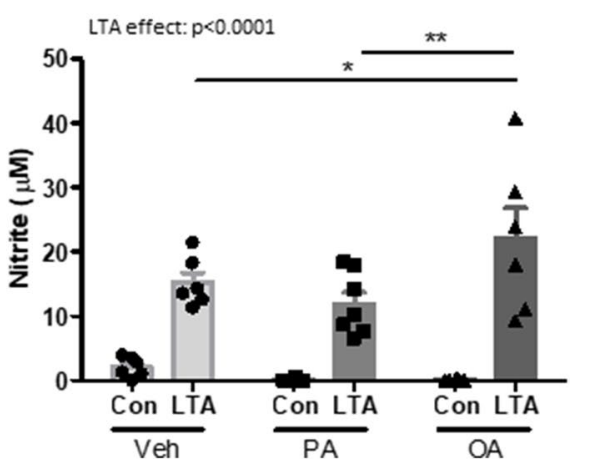

within a 12 - to 20 -week feeding period [52, 82]. More recently, inflammatory indicators have been reported in hippocampus and amygdala within 3 days of a high-fat diet comprised of SFA, MUFA and PUFA combined [83]. Heightened PA and OA levels have been identified in the brain under neurodegenerative conditions [73, 84]. In light of the prominent microglial regulation we observed following acute application of these dietary fats in vitro, we sought to examine whether chronic exposure to PA and OA in isolation would similarly impact inflammatory processes the brain in the absence of a subsequent inflammatory challenge. Despite their obesogenic phenotype [56], we determined that a 12-week diet comprised of $45 \%$ total $\mathrm{kCal}$ from either SFA or MUFA did not disrupt the expression of synaptic proteins in either cortical or hippocampal tissue. While more extensive analysis is required to fully evaluate the potential impact of these diets on neuronal morphology and synaptic integrity, our limited evaluation did not support gross alteration in synaptic density. Moreover, although we identified some dysregulation in NO expression in brains of SFA- relative to MUFA-fed animals, these changes were not indicative of robust microglial activation. These findings indicate that the 12-week feeding period with either high-SFA or -MUFA in isolation was insufficient to drive marked pathological consequences within the brain. However, we also recognise that the analysis within the current study was limited to specific hippocampal and cortical brain regions, and therefore we cannot conclude that a 12-week obesogenic diet rich in SFA or MUFA in isolation does not result in more regionspecific effects. Exposure to higher concentration of a multifat diet as demonstrated by Lainez and colleagues [52] and Butler and colleagues [83], and/or longer duration of feeding such as employed by Jeon et al. [82], is likely necessary to see significant deterioration in integrity of brain tissues concomitant with inflammatory changes.

An important outcome from the current study is the caution of examining cellular responses in isolation. This is particularly true for obesity-related inflammation, given the multi-cellular nature of the condition. Our in vitro examination indicated that the inflammatory changes in the brain in response to dietary fats are likely restricted to microglia, and moreover are mitigated by neuronal-derived mediators. Despite responding similarly to TLR agonists, neurons are thought to utilise different downstream mechanisms to process these signals [18], which likely accounts for their lack of responsiveness to fatty acids in our study. However, the bi-directional communication that exists between microglia and neurons includes an ever-growing list of molecules 
Fig. 6 A 12-week fat-rich diet does not alter synaptic density in cortex and hippocampus. Cortical and hippocampal tissue was isolated from C57BL/6 mice, following 12-week feeding with obesogenic diets rich in palmitic acid (SFA; $45 \%$ total $\mathrm{kCal}$ ) or oleic acid (MUFA; $45 \%$ total $\mathrm{kCal}$ ), or a nonobesogenic, nutrient-matched control diet (chow; 10\% total $\mathrm{kCal}$ from fat). Protein lysates were assessed for the expression of PSD-95, drebrin and synaptophysin $(\mathrm{SYN})$ in cortex $(\mathbf{a}, \mathbf{c}$, e, g) and hippocampus (b, d, f, h), respectively. $N=3$ animals per group. Data is presented as mean \pm SEM overlaid with individual data points. Statistical differences were assessed using one-way ANOVA. Inserts illustrate representative immunoreactive bands for PSD95, drebrin, SYN and $\beta$-actin (triplicate samples)
Cortex

a
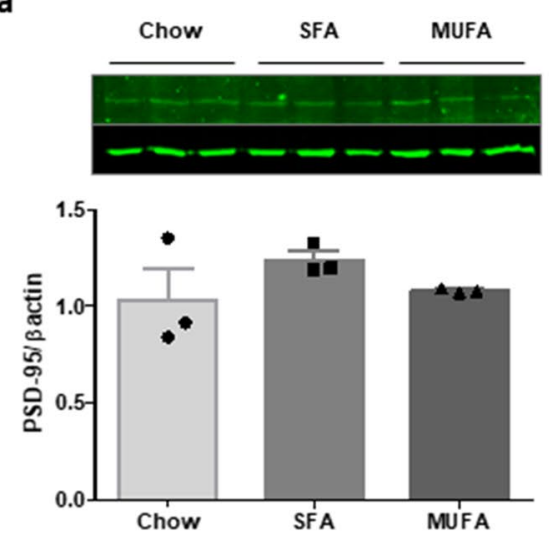

c

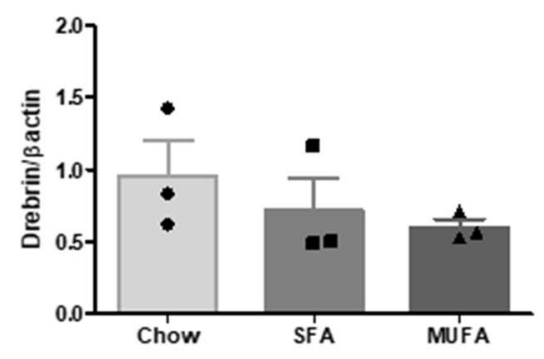

e

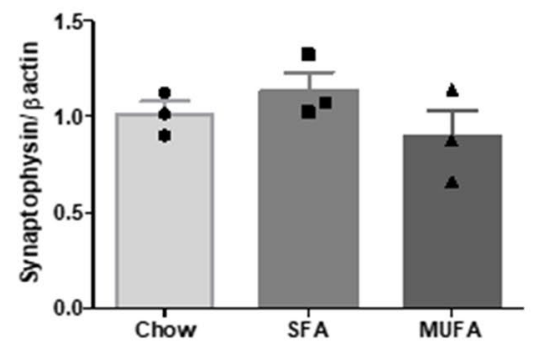

g

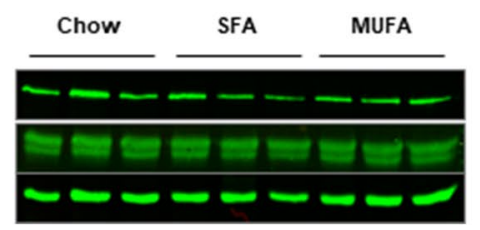

Hippocampus

b
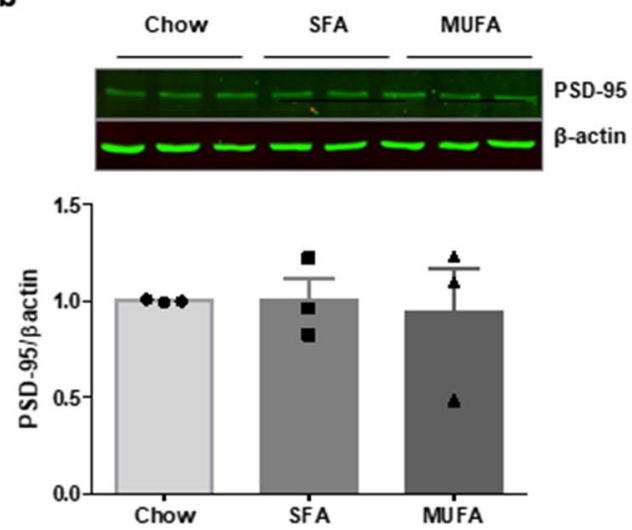

d

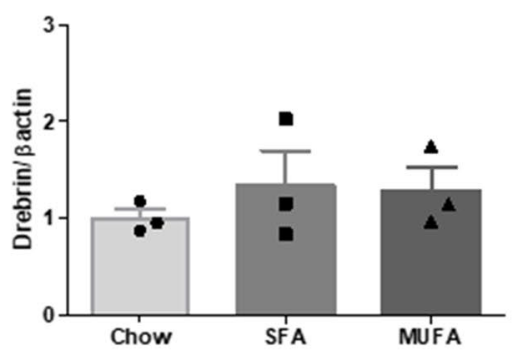

f

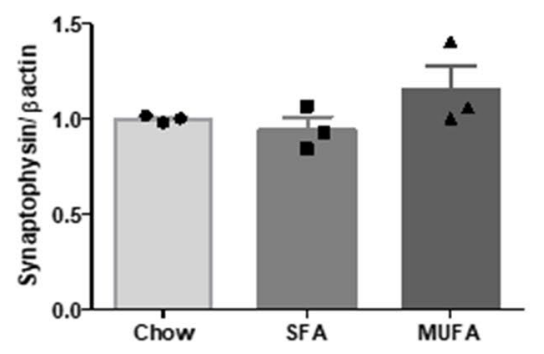

h

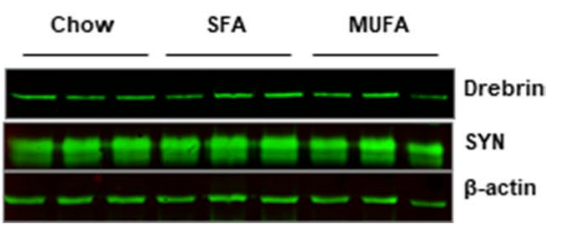

known to either directly or indirectly downregulate microglial function $[85,86]$. Plausibly therefore, this interaction is a contributing factor to the paucity of inflammatory changes we identified in the brain following a 12 -week $45 \%$ high-fat diet, and the preservation of synaptic integrity.

The infiltration of peripheral macrophages into the CNS is thought to contribute significantly to the neuroinflammatory consequences of obesity $[49,52]$. To model this interaction in vitro, we incubated macrophages with soluble factors isolated from the brain of DIO animals [28]. We found that TNF- $\alpha$ secretion from macrophages was similarly supressed by exposure brain extract from each feeding group, independently of diet composition or obesity. This perhaps illustrates a similar response of macrophages to the inhibitory influence of neuronal-derived factors. Surprisingly, while exposure to brain extract from chow- and SFA-fed mice enhanced NO production in macrophages, this was not evident when cells were incubated with extract from MUFA-fed mice. A 
Fig. 7 Expression of NO expression is differently regulated in brain extract from SFA- and MUFA-fed animals. Cortical and hippocampal tissue was isolated from high-fatinduced obese animals (SFA, MUFA) and non-obese controls (chow). Protein lysates were assessed for the expression of iNOS and nNOS from cortex (a, c) and hippocampus (b, d), respectively. Soluble brain extract (SBE) prepared from cortical tissue of DIO mice was assessed for expression of nitrite (e (i)). Correlations were made between concentration of nitrite (e (ii)) measured in SBE from SFA versus MUFA fed animals $(N=3-4$ animals per group). BMDMs from naïve animals were incubated with $\mathrm{SBE}(0.25 \mathrm{mg} / \mathrm{mL}$ total protein) for $24 \mathrm{~h}$. Supernatant expression of TNF- $\alpha(\mathbf{f})$ and nitrite (g) was determined. Statistical comparisons were made using one-way ANOVA, followed by Neuman-Keuls analysis. ${ }^{*} p<0.05, * * * p<0.001(n=5-8$ replicates, from 3 independent experiments). Data is presented as mean \pm SEM. Inserts illustrate representative immunoreactive bands for iNOS $(\mathbf{a}, \mathbf{b})$, $\mathrm{nNOS}(\mathbf{c}, \mathbf{d})$ and $\beta$-actin $(\mathbf{a}-\mathbf{d}$, triplicate samples)

\section{Cortex}

a
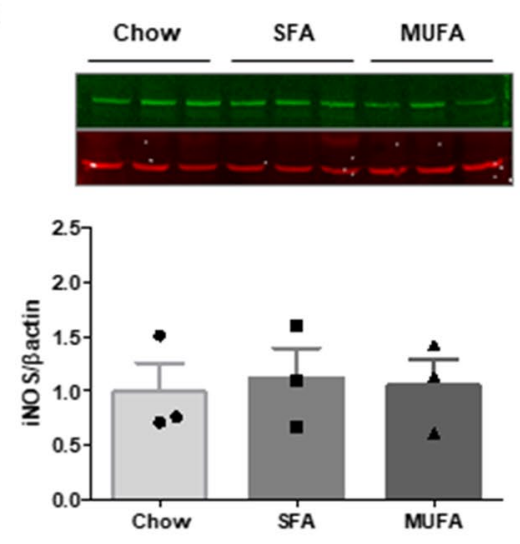

C
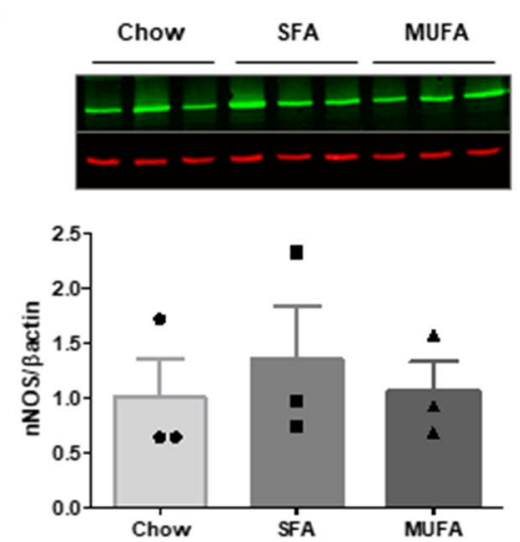

e (i)

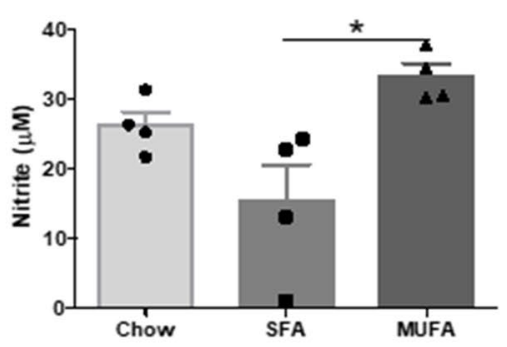

f

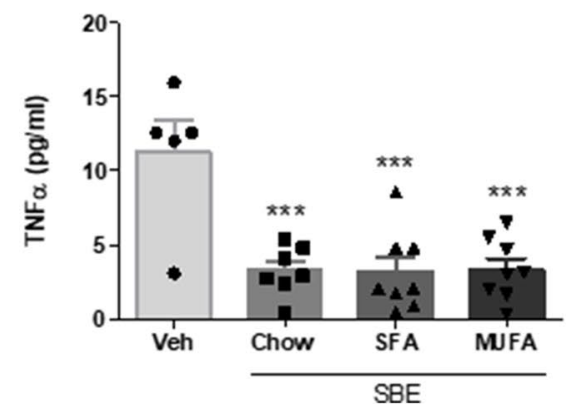

Hippocampus

b

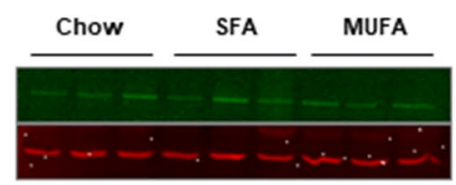

iNOS $\beta$-actin

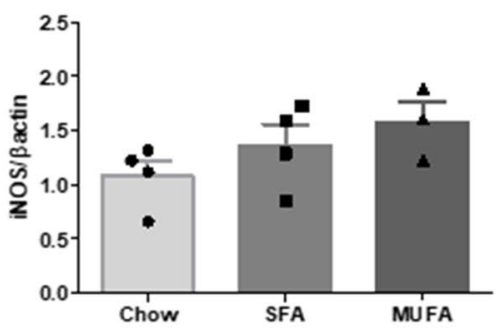

d
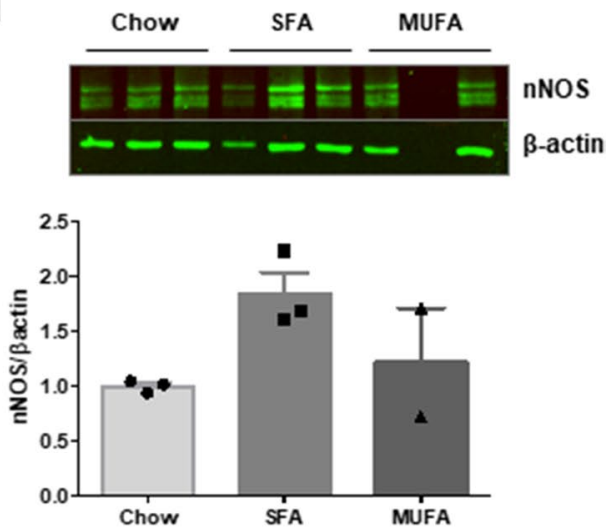

(ii)

$(r=-0.9954, p=0.0046)$

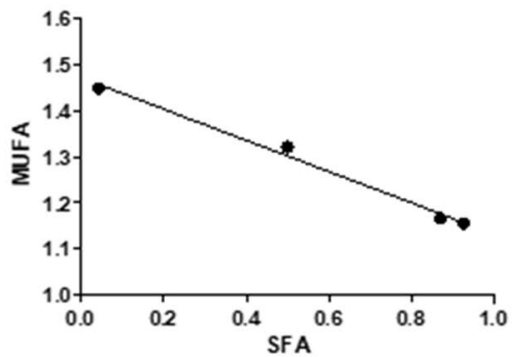

g

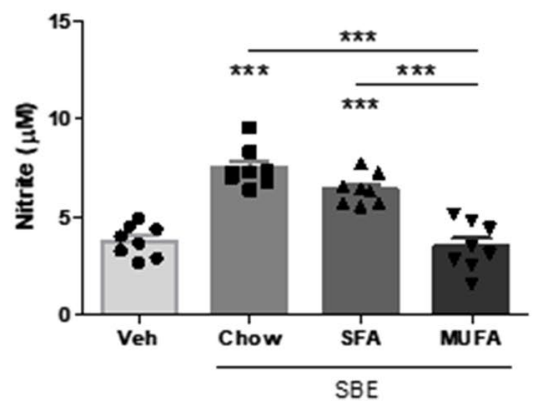


consistent finding throughout the study has been enhanced production of NO, particularly in response to MUFA. Under inflammatory conditions, including TLR stimulation, NO is also an essential component of the host-defence response [87]. However, its over-production promotes cellular toxicity and accordingly has been widely implicated in disease pathogenesis [80]. A previous exploration revealed that PA and $\mathrm{OA}$ induce a concentration-dependent increase in NO production from LPS-stimulated macrophages [88], while a subsequent study reported that an acute $1 \mathrm{~h}$ pre-exposure to OA had the opposing effect on LPS-induced NO in microglia [89]. Based on our in vitro analysis of direct OA exposure and ex vivo brain extract from MUFA-fed animals, we can speculate that excess NO production in the brain in response to a MUFA-rich diet is likely driven by infiltrating macrophages and not microglia. Taken together, this evidence points towards a potential difference in the response to $\mathrm{OA}$ following post-prandial and chronic dietary exposure [64]. It is also tempting to speculate that disruption in the balance of NO production may therefore account for some of the apparently conflicting outcomes of the healthy 'Mediterranean diet' compared with the MUFA-rich obesogenic diet.

The current study focused on investigating the role of dietary fats as inflammatory regulators. Our findings reveal that exposure to fatty acids may determine the response of microglia to subsequent inflammatory challenge by a TLR2targetting stimulus, which may have a critical impact on neurodegenerative disease processes. We further highlight $\mathrm{NO}$ as an important mediator of fatty acid-related sensitivity to neuroinflammation, under acute and chronic conditions. Moreover, the current findings support the proposal that the influence of a HFD on the brain is likely to be sensitive to both the total fat content and diet duration. However, we also recognise that the obese state is associated with the overconsumption of a combination of nutrients, contributing to intracellular stress and activation of an immune response [31]. As fats are rarely consumed in isolation as part of an obesogenic diet, we must also consider the influence of secondary metabolic perturbations resulting from sugar and cholesterol intake which are known to impact negatively on cognition [90], and act as primary risk factors for AD [91]. Replacing SFA for MUFA within the obesogenic diet may indeed convey some protection against cognitive decline. However, the current findings suggest that this will likely be coupled with mitigation of obesity-associated comorbidities rather than a direct influence on inflammatory processes in the brain.

Author Contribution Anne-Marie Howe: conceptualization, methodology, formal analysis, investigation, writing-original draft, writingreview and editing, visualisation. Sinéad Burke: investigation, formal analysis. Marcella E. O'Reilly: methodology, investigation. Fiona C. McGillicuddy: conceptualization, methodology, writing-review and editing, funding acquisition. Derek A. Costello: conceptualization, methodology, investigation, writing-original draft, writing-review and editing, visualisation, supervision, funding acquisition.

Funding Open Access funding provided by the IReL Consortium. AH was supported by a Graduate Research Scholarship from the UCD School of Biomolecular \& Biomedical Science awarded to DAC. A portion of this work was supported by a Wellcome Trust Career Development fellowship awarded to FMcG (097311/Z/11/Z).

Data Availability The datasets generated during and/or analysed during the current study are available from the corresponding author upon reasonable request.

Code Availability Not applicable.

\section{Declarations}

Ethics Approval All animal-based experiments were carried out following approval by the UCD Animal Research Ethics Committee, and with individual and project authorisation of the Health Products Regulatory Authority (HPRA) of Ireland.

Consent to Participate Not applicable.

Consent for Publication All authors consent to publication of this manuscript.

Conflict of Interest The authors declare no competing interests.

Open Access This article is licensed under a Creative Commons Attribution 4.0 International License, which permits use, sharing, adaptation, distribution and reproduction in any medium or format, as long as you give appropriate credit to the original author(s) and the source, provide a link to the Creative Commons licence, and indicate if changes were made. The images or other third party material in this article are included in the article's Creative Commons licence, unless indicated otherwise in a credit line to the material. If material is not included in the article's Creative Commons licence and your intended use is not permitted by statutory regulation or exceeds the permitted use, you will need to obtain permission directly from the copyright holder. To view a copy of this licence, visit http://creativecommons.org/licenses/by/4.0/.

\section{References}

1. DiSabato DJ, Quan N, Godbout JP (2016) Neuroinflammation: the devil is in the details. J Neurochem 139(Suppl 2):136-153. https://doi.org/10.1111/jnc.13607

2. Streit WJ, Mrak RE, Griffin WST (2004) Microglia and neuroinflammation: a pathological perspective. J Neuroinflammation 1(1):14

3. Kim Y-K, Jeon SW (2018) Neuroinflammation and the immunekynurenine pathway in anxiety disorders. Curr Neuropharmacol 16(5):574-582

4. Salim S, Chugh G, Asghar M (2012) Inflammation in anxiety. In: Advances in protein chemistry and structural biology, vol 88. Elsevier, pp 1-25

5. Furtado M, Katzman MA (2015) Examining the role of neuroinflammation in major depression. Psychiatry Res 229(1-2):27-36

6. Hurley LL, Tizabi Y (2013) Neuroinflammation, neurodegeneration, and depression. Neurotox Res 23(2):131-144 
7. Monahan AJ, Warren M, Carvey PM (2008) Neuroinflammation and peripheral immune infiltration in Parkinson's disease: an autoimmune hypothesis. Cell Transplant 17(4):363-372

8. Tansey MG, Goldberg MS (2010) Neuroinflammation in Parkinson's disease: its role in neuronal death and implications for therapeutic intervention. Neurobiol Dis 37(3):510-518

9. Heneka MT, Carson MJ, El Khoury J, Landreth GE, Brosseron F, Feinstein DL, Jacobs AH, Wyss-Coray T, Vitorica J, Ransohoff RM, Herrup K, Frautschy SA, Finsen B, Brown GC, Verkhratsky A, Yamanaka K, Koistinaho J, Latz E, Halle A, Petzold GC, Town T, Morgan D, Shinohara ML, Perry VH, Holmes C, Bazan NG, Brooks DJ, Hunot S, Joseph B, Deigendesch N, Garaschuk O, Boddeke E, Dinarello CA, Breitner JC, Cole GM, Golenbock DT, Kummer MP (2015) Neuroinflammation in Alzheimer's disease. The Lancet Neurology 14(4):388-405. https://doi.org/10.1016/ s1474-4422(15)70016-5

10. Norden DM, Godbout JP (2013) Microglia of the aged brain: primed to be activated and resistant to regulation. Neuropathol Appl Neurobiol 39(1):19-34

11. Glass CK, Saijo K, Winner B, Marchetto MC, Gage FH (2010) Mechanisms underlying inflammation in neurodegeneration. Cell 140(6):918-934

12. Costello DA, Lynch MA (2013) Toll-like receptor 3 activation modulates hippocampal network excitability, via glial production of interferon-beta. Hippocampus 23(8):696-707. https://doi.org/ 10.1002/hipo.22129

13. Costello DA, Lyons A, Denieffe S, Browne TC, Cox FF, Lynch MA (2011) Long term potentiation is impaired in membrane glycoprotein CD200-deficient mice: a role for Toll-like receptor activation. J Biol Chem 286(40):34722-34732. https://doi.org/10. 1074/jbc.M111.280826

14. Costello DA, Watson MB, Cowley TR, Murphy N, Murphy Royal C, Garlanda C, Lynch MA (2011) Interleukin-1alpha and HMGB1 mediate hippocampal dysfunction in SIGIRR-deficient mice. J Neurosci 31(10):3871-3879. https://doi.org/10.1523/JNEUR OSCI.6676-10.2011

15. Hanke ML, Kielian T (2011) Toll-like receptors in health and disease in the brain: mechanisms and therapeutic potential. Clin Sci (Lond) 121(9):367-387. https://doi.org/10.1042/CS20110164

16. Maroso M, Balosso S, Ravizza T, Liu J, Bianchi ME, Vezzani A (2011) Interleukin-1 type 1 receptor/Toll-like receptor signalling in epilepsy: the importance of IL-1beta and high-mobility group box 1. J Intern Med 270(4):319-326. https://doi.org/10.1111/j. 1365-2796.2011.02431.x

17. Jones AC, Pinki F, Stewart GS, Costello DA (2021) Inhibition of urea transporter (UT)-B modulates LPS-induced inflammatory responses in BV2 microglia and N2a neuroblastoma cells. Neurochem Res. https://doi.org/10.1007/s11064-021-03283-4

18. Okun E, Griffioen KJ, Mattson MP (2011) Toll-like receptor signaling in neural plasticity and disease. Trends Neurosci 34(5):269281. https://doi.org/10.1016/j.tins.2011.02.005

19. Hayward JH, Lee SJ (2014) A decade of research on TLR2 discovering its pivotal role in glial activation and neuroinflammation in neurodegenerative diseases. Exp Neurobiol 23(2):138-147. https://doi.org/10.5607/en.2014.23.2.138

20. Kim C, Ho DH, Suk JE, You S, Michael S, Kang J, Joong Lee S, Masliah E, Hwang D, Lee HJ, Lee SJ (2013) Neuron-released oligomeric alpha-synuclein is an endogenous agonist of TLR2 for paracrine activation of microglia. Nat Commun 4:1562. https:// doi.org/10.1038/ncomms2534

21. Liu S, Liu Y, Hao W, Wolf L, Kiliaan AJ, Penke B, Rube CE, Walter J, Heneka MT, Hartmann T, Menger MD, Fassbender K (2012) TLR2 is a primary receptor for Alzheimer's amyloid beta peptide to trigger neuroinflammatory activation. J immunol (Baltimore, Md : 1950) 188(3):1098-1107. https://doi.org/10.4049/jimmunol. 1101121
22. Howe AM, Cosgrave A, O’Murchu M, Britchfield C, Mulvagh A, Fernandez-Perez I, Dykstra M, Jones AC, Costello DA (2020) Characterising lipoteichoic acid as an in vitro model of acute neuroinflammation. Int Immunopharmacol 85:106619. https://doi.org/ 10.1016/j.intimp.2020.106619

23. Costello DA, Carney DG, Lynch MA (2015) alpha-TLR2 antibody attenuates the Abeta-mediated inflammatory response in microglia through enhanced expression of SIGIRR. Brain Behav Immun 46:70-79. https://doi.org/10.1016/j.bbi.2015.01.005

24. McDonald CL, Hennessy E, Rubio-Araiz A, Keogh B, McCormack W, McGuirk P, Reilly M, Lynch MA (2016) Inhibiting TLR2 activation attenuates amyloid accumulation and glial activation in a mouse model of Alzheimer's disease. Brain Behav Immun 58:191-200. https://doi.org/10.1016/j.bbi.2016.07.143

25. Blau CW, Cowley TR, O'Sullivan J, Grehan B, Browne TC, Kelly L, Birch A, Murphy N, Kelly AM, Kerskens CM, Lynch MA (2012) The age-related deficit in LTP is associated with changes in perfusion and blood-brain barrier permeability. Neurobiol Aging 33 (5):1005 e1023-1035. https://doi.org/10.1016/j.neurobiola ging.2011.09.035

26. Minogue AM, Jones RS, Kelly RJ, McDonald CL, Connor TJ, Lynch MA (2014) Age-associated dysregulation of microglial activation is coupled with enhanced blood-brain barrier permeability and pathology in APP/PS1 mice. Neurobiol Aging 35(6):1442-1452. https://doi.org/10.1016/j.neurobiolaging.2013. 12.026

27. Barrett JP, Costello DA, O'Sullivan J, Cowley TR, Lynch MA (2015) Bone marrow-derived macrophages from aged rats are more responsive to inflammatory stimuli. J Neuroinflammation 12:67. https://doi.org/10.1186/s12974-015-0287-7

28. Costello DA, Keenan K, McManus RM, Falvey A, Lynch MA (2016) The age-related neuroinflammatory environment promotes macrophage activation, which negatively impacts synaptic function. Neurobiol Aging 43:140-148. https://doi.org/10.1016/j. neurobiolaging.2016.04.001

29. Wolfe H, Minogue AM, Rooney S, Lynch MA (2018) Infiltrating macrophages contribute to age-related neuroinflammation in C57/BL6 mice. Mech Ageing Dev 173:84-91. https://doi.org/10. 1016/j.mad.2018.05.003

30. Kelly T, Yang W, Chen CS, Reynolds K, He J (2008) Global burden of obesity in 2005 and projections to 2030. Int J Obes (Lond) 32(9):1431-1437. https://doi.org/10.1038/ijo.2008.102

31. Gregor MF, Hotamisligil GS (2011) Inflammatory mechanisms in obesity. Annu Rev Immunol 29:415-445. https://doi.org/10.1146/ annurev-immunol-031210-101322

32. Miller AA, Spencer SJ (2014) Obesity and neuroinflammation: a pathway to cognitive impairment. Brain Behav Immun 42:10-21. https://doi.org/10.1016/j.bbi.2014.04.001

33. Weisberg SP, McCann D, Desai M, Rosenbaum M, Leibel RL, Ferrante AW Jr (2003) Obesity is associated with macrophage accumulation in adipose tissue. J Clin Invest 112(12):1796-1808. https://doi.org/10.1172/JCI19246

34. Odegaard JI, Chawla A (2013) Pleiotropic actions of insulin resistance and inflammation in metabolic homeostasis. Science 339(6116):172-177. https://doi.org/10.1126/science.1230721

35. Eckel RH, Barouch WW, Ershow AG (2002) Report of the National Heart, Lung, and Blood Institute-National Institute of Diabetes and Digestive and Kidney Diseases Working Group on the pathophysiology of obesity-associated cardiovascular disease. Circulation 105(24):2923-2928. https://doi.org/10.1161/01.cir. $0000017823.53114 .4 \mathrm{c}$

36. Michelet X, Dyck L, Hogan A, Loftus RM, Duquette D, Wei K, Beyaz S, Tavakkoli A, Foley C, Donnelly R, O'Farrelly C, Raverdeau M, Vernon A, Pettee W, O'Shea D, Nikolajczyk BS, Mills KHG, Brenner MB, Finlay D, Lynch L (2018) Metabolic reprogramming of natural killer cells in obesity limits antitumor 
responses. Nat Immunol 19(12):1330-1340. https://doi.org/10. 1038/s41590-018-0251-7

37. Peeters A, Barendregt JJ, Willekens F, Mackenbach JP, Al Mamun A, Bonneux L, Nedcom tNE, Demography Compression of Morbidity Research G (2003) Obesity in adulthood and its consequences for life expectancy: a life-table analysis. Ann Intern Med 138 (1):24-32. https://doi.org/10.7326/0003-4819-138-1-20030 1070-00008

38. Sabia S, Kivimaki M, Shipley MJ, Marmot MG, Singh-Manoux A (2009) Body mass index over the adult life course and cognition in late midlife: the Whitehall II Cohort Study. Am J Clin Nutr 89(2):601-607. https://doi.org/10.3945/ajcn.2008.26482

39. Debette S, Seshadri S, Beiser A, Au R, Himali JJ, Palumbo C, Wolf PA, DeCarli C (2011) Midlife vascular risk factor exposure accelerates structural brain aging and cognitive decline. Neurology 77(5):461-468. https://doi.org/10.1212/WNL.0b013e3182 $27 \mathrm{~b} 227$

40. Dahl AK, Hassing LB (2013) Obesity and cognitive aging. Epidemiol Rev 35:22-32. https://doi.org/10.1093/epirev/mxs002

41. Wolf PA, Beiser A, Elias MF, Au R, Vasan RS, Seshadri S (2007) Relation of obesity to cognitive function: importance of central obesity and synergistic influence of concomitant hypertension The Framingham Heart Study. Curr Alzheimer Res 4(2):111-116. https://doi.org/10.2174/156720507780362263

42. Martin-Jimenez CA, Gaitan-Vaca DM, Echeverria V, Gonzalez J, Barreto GE (2017) Relationship Between obesity, Alzheimer's disease, and Parkinson's disease: an astrocentric view. Mol Neurobiol 54(9):7096-7115. https://doi.org/10.1007/ s12035-016-0193-8

43. Lee YH, Martin JM, Maple RL, Tharp WG, Pratley RE (2009) Plasma amyloid-beta peptide levels correlate with adipocyte amyloid precursor protein gene expression in obese individuals. Neuroendocrinology 90(4):383-390. https://doi.org/10.1159/00023 5555

44. Jahangiri A, Wilson PG, Hou T, Brown A, King VL, Tannock LR (2013) Serum amyloid A is found on ApoB-containing lipoproteins in obese humans with diabetes. Obesity (Silver Spring) 21(5):993-996. https://doi.org/10.1002/oby.20126

45. Refolo LM, Malester B, LaFrancois J, Bryant-Thomas T, Wang R, Tint GS, Sambamurti K, Duff K, Pappolla MA (2000) Hypercholesterolemia accelerates the Alzheimer's amyloid pathology in a transgenic mouse model. Neurobiol Dis 7(4):321-331. https:// doi.org/10.1006/nbdi.2000.0304

46. Julien C, Tremblay C, Phivilay A, Berthiaume L, Émond V, Julien $\mathrm{P}$, Calon F (2010) High-fat diet aggravates amyloid-beta and tau pathologies in the 3xTg-AD mouse model. Neurobiol Aging 31(9):1516-1531

47. Pohl J, Woodside B, Luheshi GN (2009) Changes in hypothalamically mediated acute-phase inflammatory responses to lipopolysaccharide in diet-induced obese rats. Endocrinology 150(11):4901-4910. https://doi.org/10.1210/en.2009-0526

48. Dinel AL, Andre C, Aubert A, Ferreira G, Laye S, Castanon N (2011) Cognitive and emotional alterations are related to hippocampal inflammation in a mouse model of metabolic syndrome. PLoS ONE 6(9):e24325. https://doi.org/10.1371/journal.pone. 0024325

49. Stranahan AM, Hao S, Dey A, Yu X, Baban B (2016) Blood-brain barrier breakdown promotes macrophage infiltration and cognitive impairment in leptin receptor-deficient mice. J Cereb Blood Flow Metab 36(12):2108-2121

50. Rhea EM, Salameh TS, Logsdon AF, Hanson AJ, Erickson MA, Banks WA (2017) Blood-Brain Barriers in Obesity. AAPS J 19(4):921-930. https://doi.org/10.1208/s12248-017-0079-3

51. Buckman LB, Hasty AH, Flaherty DK, Buckman CT, Thompson MM, Matlock BK, Weller K, Ellacott KL (2014) Obesity induced by a high-fat diet is associated with increased immune cell entry into the central nervous system. Brain Behav Immun 35:33-42. https://doi.org/10.1016/j.bbi.2013.06.007

52. Lainez NM, Jonak CR, Nair MG, Ethell IM, Wilson EH, Carson MJ, Coss D (2018) Diet-induced obesity elicits macrophage infiltration and reduction in spine density in the hypothalami of male but not female mice. Front Immunol 9

53. Gustafson DR, Karlsson C, Skoog I, Rosengren L, Lissner L, Blennow K (2007) Mid-life adiposity factors relate to blood-brain barrier integrity in late life. J Intern Med 262(6):643-650. https:// doi.org/10.1111/j.1365-2796.2007.01869.x

54. Montagne A, Barnes SR, Sweeney MD, Halliday MR, Sagare AP, Zhao Z, Toga AW, Jacobs RE, Liu CY, Amezcua L (2015) Blood-brain barrier breakdown in the aging human hippocampus. Neuron 85(2):296-302

55. Carta G, Murru E, Banni S, Manca C (2017) Palmitic acid: physiological role, metabolism and nutritional implications. Front Physiol 8:902

56. O'Reilly M, Dillon E, Guo W, Finucane O, McMorrow A, Murphy A, Lyons C, Jones D, Ryan M, Gibney M, Gibney E, Brennan L, de la Llera MM, Reilly MP, Roche HM, McGillicuddy FC (2016) High-density lipoprotein proteomic composition, and not efflux capacity, reflects differential modulation of reverse cholesterol transport by saturated and monounsaturated fat diets. Circulation 133(19):1838-1850. https://doi.org/10.1161/CIRCULATIO NAHA.115.020278

57. Milanski M, Degasperi G, Coope A, Morari J, Denis R, Cintra DE, Tsukumo DM, Anhe G, Amaral ME, Takahashi HK (2009) Saturated fatty acids produce an inflammatory response predominantly through the activation of TLR4 signaling in hypothalamus: implications for the pathogenesis of obesity. J Neurosci 29(2):359-370

58. Petrov D, Pedros I, Artiach G, Sureda FX, Barroso E, Pallas M, Casadesus G, Beas-Zarate C, Carro E, Ferrer I, Vazquez-Carrera M, Folch J (1852) Camins A (2015) High-fat diet-induced deregulation of hippocampal insulin signaling and mitochondrial homeostasis deficiences contribute to Alzheimer disease pathology in rodents. Biochim Biophys Acta 9:1687-1699. https://doi.org/10. 1016/j.bbadis.2015.05.004

59. Joffre C, Dinel AL, Chataigner M, Pallet V, Laye S (2020) n-3 Polyunsaturated fatty acids and their derivates reduce neuroinflammation during aging. Nutrients 12 (3). https://doi.org/10. 3390/nu12030647

60. Chen X, Chen C, Fan S, Wu S, Yang F, Fang Z, Fu H, Li Y (2018) Omega-3 polyunsaturated fatty acid attenuates the inflammatory response by modulating microglia polarization through SIRT1mediated deacetylation of the HMGB1/NF-кB pathway following experimental traumatic brain injury. J Neuroinflammation 15(1): 116

61. Barberger-Gateau P, Samieri C, Féart C, Plourde M (2011) Dietary omega 3 polyunsaturated fatty acids and Alzheimer's disease: interaction with apolipoprotein E genotype. Curr Alzheimer Res 8(5):479-491

62. Scarmeas N, Stern Y, Mayeux R, Manly JJ, Schupf N, Luchsinger JA (2009) Mediterranean diet and mild cognitive impairment. Arch Neurol 66(2):216-225

63. Lauretti E, Iuliano L, Praticò D (2017) Extra-virgin olive oil ameliorates cognition and neuropathology of the $3 \mathrm{xTg}$ mice: role of autophagy. Annals of clinical and translational neurology 4(8):564-574

64. Toscano R, Millan-Linares MC, Lemus-Conejo A, Claro C, Sanchez-Margalet V, Montserrat-de la Paz S (2020) Postprandial triglyceride-rich lipoproteins promote M1/M2 microglia polarization in a fatty-acid-dependent manner. J Nutr Biochem 75:108248. https://doi.org/10.1016/j.jnutbio.2019.108248

65. Ajuwon KM, Spurlock ME (2005) Palmitate activates the NFkappaB transcription factor and induces IL-6 and TNFalpha 
expression in 3T3-L1 adipocytes. J Nutr 135(8):1841-1846. https://doi.org/10.1093/jn/135.8.1841

66. Nguyen MT, Favelyukis S, Nguyen AK, Reichart D, Scott PA, Jenn A, Liu-Bryan R, Glass CK, Neels JG, Olefsky JM (2007) A subpopulation of macrophages infiltrates hypertrophic adipose tissue and is activated by free fatty acids via Toll-like receptors 2 and 4 and JNK-dependent pathways. J Biol Chem 282(48):3527935292. https://doi.org/10.1074/jbc.M706762200

67. Beaulieu J, Costa G, Renaud J, Moitie A, Glemet H, Sergi D, Martinoli MG (2021) The neuroinflammatory and neurotoxic potential of palmitic acid is mitigated by oleic acid in microglial cells and microglial-neuronal co-cultures. Mol Neurobiol 58(6):3000-3014. https://doi.org/10.1007/s12035-021-02328-7

68. Lee JY, Plakidas A, Lee WH, Heikkinen A, Chanmugam P, Bray G, Hwang DH (2003) Differential modulation of Toll-like receptors by fatty acids: preferential inhibition by $\mathrm{n}-3$ polyunsaturated fatty acids. J Lipid Res 44(3):479-486. https://doi.org/10.1194/ jlr.M200361-JLR200

69. Lee JY, Zhao L, Youn HS, Weatherill AR, Tapping R, Feng L, Lee WH, Fitzgerald KA, Hwang DH (2004) Saturated fatty acid activates but polyunsaturated fatty acid inhibits Toll-like receptor 2 dimerized with Toll-like receptor 6 or 1 . J Biol Chem 279(17):16971-16979. https://doi.org/10.1074/jbc.M312990200

70. Tracy LM, Bergqvist F, Ivanova EV, Jacobsen KT, Iverfeldt K (2013) Exposure to the saturated free fatty acid palmitate alters BV-2 microglia inflammatory response. J Mol Neurosci 51(3):805-812. https://doi.org/10.1007/s12031-013-0068-7

71. Kappe C, Tracy LM, Patrone C, Iverfeldt K, Sjöholm A (2012) GLP-1 secretion by microglial cells and decreased CNS expression in obesity. J Neuroinflammation 9(1):276. https://doi.org/10. 1186/1742-2094-9-276

72. Li L, Li L, Zhang J, Huang S, Liu W, Wang Z, Liang S, Tao J, Chen L (2020) Disease stage-associated alterations in learning and memory through the electroacupuncture modulation of the cortical microglial M1/M2 polarization in mice with Alzheimer's disease. Neural Plast 2020:8836173. https://doi.org/10.1155/2020/ 8836173

73. Fraser T, Tayler H, Love S (2010) Fatty acid composition of frontal, temporal and parietal neocortex in the normal human brain and in Alzheimer's disease. Neurochem Res 35(3):503-513

74. Jana M, Palencia CA, Pahan K (2008) Fibrillar amyloid-beta peptides activate microglia via TLR2: implications for Alzheimer's disease. J immunol (Baltimore Md : 1950) 181(10):7254-7262

75. Davis JE, Walker-Daniels J, Spurlock ME (2009) Absence of Tolllike receptor-2 (Tlr2) attenuates diet induced obesity and adipose tissue inflammation and insulin resistance. Federation of American Societies for Experimental Biology,

76. Lancaster GI, Langley KG, Berglund NA, Kammoun HL, Reibe S, Estevez E, Weir J, Mellett NA, Pernes G, Conway JRW, Lee MKS, Timpson P, Murphy AJ, Masters SL, Gerondakis S, Bartonicek N, Kaczorowski DC, Dinger ME, Meikle PJ, Bond PJ, Febbraio MA (2018) Evidence that TLR4 is not a receptor for saturated fatty acids but mediates lipid-induced inflammation by reprogramming macrophage metabolism. Cell Metab 27 (5):1096-1110 e1095. https://doi.org/10.1016/j.cmet.2018.03.014

77. Matsui Y, Tomaru U, Miyoshi A, Ito T, Fukaya S, Miyoshi H, Atsumi T, Ishizu A (2014) Overexpression of TNF- $\alpha$ converting enzyme promotes adipose tissue inflammation and fibrosis induced by high fat diet. Exp Mol Pathol 97(3):354-358
78. Singh B, Parsaik AK, Mielke MM, Erwin PJ, Knopman DS, Petersen RC, Roberts RO (2014) Association of mediterranean diet with mild cognitive impairment and Alzheimer's disease: a systematic review and meta-analysis. J Alzheimers Dis 39(2):271-282

79. Baer DJ, Judd JT, Clevidence BA, Tracy RP (2004) Dietary fatty acids affect plasma markers of inflammation in healthy men fed controlled diets: a randomized crossover study. Am J Clin Nutr 79(6):969-973

80. Steinert JR, Chernova T, Forsythe ID (2010) Nitric oxide signaling in brain function, dysfunction, and dementia. Neuroscientist 16(4):435-452. https://doi.org/10.1177/1073858410366481

81. Reis PA, de Albuquerque CFG, Gutierrez T, Silva AR, de Castro Faria Neto H (2017) Role of nitric oxide synthase in the function of the central nervous system under normal and infectious conditions. Nitric Oxide Synthase-Simple Enzyme-Complex Roles London: InTech:55-70

82. Jeon BT, Jeong EA, Shin HJ, Lee Y, Lee DH, Kim HJ, Kang SS, Cho GJ, Choi WS, Roh GS (2012) Resveratrol attenuates obesity-associated peripheral and central inflammation and improves memory deficit in mice fed a high-fat diet. Diabetes 61(6): 1444-1454

83. Butler MJ, Cole RM, Deems NP, Belury MA, Barrientos RM (2020) Fatty food, fatty acids, and microglial priming in the adult and aged hippocampus and amygdala. Brain Behav Immun 89:145-158. https://doi.org/10.1016/j.bbi.2020.06.010

84. Fabelo N, Martín V, Santpere G, Marín R, Torrent L, Ferrer I, Díaz M (2011) Severe alterations in lipid composition of frontal cortex lipid rafts from Parkinson's disease and incidental Parkinson's disease. Mol Med 17(9-10):1107-1118

85. Cunningham C (2013) Microglia and neurodegeneration: the role of systemic inflammation. Glia 61(1):71-90

86. Park HR, Kim J-Y, Park K-Y, Lee J (2011) Lipotoxicity of palmitic acid on neural progenitor cells and hippocampal neurogenesis. Toxicological research 27(2):103

87. Abdul-Cader MS, Amarasinghe A, Abdul-Careem MF (2016) Activation of Toll-like receptor signaling pathways leading to nitric oxide-mediated antiviral responses. Adv Virol 161(8):2075-2086

88. de Lima TM, de Sa LL, Scavone C, Curi R (2006) Fatty acid control of nitric oxide production by macrophages. FEBS Lett 580(13):3287-3295. https://doi.org/10.1016/j.febslet.2006.04.091

89. Oh YT, Lee JY, Lee J, Kim H, Yoon KS, Choe W, Kang I (2009) Oleic acid reduces lipopolysaccharide-induced expression of iNOS and COX-2 in BV2 murine microglial cells: possible involvement of reactive oxygen species, p38 MAPK, and IKK/NFkappaB signaling pathways. Neurosci Lett 464(2):93-97. https:// doi.org/10.1016/j.neulet.2009.08.040

90. Jurdak N, Lichtenstein AH, Kanarek RB (2008) Diet-induced obesity and spatial cognition in young male rats. Nutr Neurosci 11(2):48-54

91. Liyanage SI, Vilekar P, Weaver DF (2019) Nutrients in Alzheimer's disease: the interaction of diet, drugs and disease. Can J Neurol Sci 46(1):23-34. https://doi.org/10.1017/cjn.2018.353

Publisher's Note Springer Nature remains neutral with regard to jurisdictional claims in published maps and institutional affiliations. 